\title{
Diatom dynamics in a coastal ecosystem affected by upwelling: coupling between species succession, circulation and biogeochemical processes
}

\author{
G. H. Tilstone ${ }^{1, *}$, B. M. Míguez ${ }^{2}$, F. G. Figueiras ${ }^{1, * *}$, E. G. Fermín ${ }^{3}$ \\ ${ }^{1}$ Instituto de Investigacións Mariñas, CSIC, Eduardo Cabello 6, 36208 Vigo, Spain \\ ${ }^{2}$ Universidade de Vigo, Facultad de Ciencias, Dpto. Física aplicada, Aptdo. 874, 36200 Vigo, Spain \\ ${ }^{3}$ Escuela de Ciencias Aplicadas del Mar, Universidad de Oriente, Boca de Río, Isla Margarita, Venezuela
}

\begin{abstract}
The typical phytoplankton succession scenario in coastal upwelling zones is high diatom growth during upwelling and flagellate dominance during water column stratification. Within the diatom/flagellate succession there exist short-term changes in diatom communities that are caused by physical, chemical and biological processes. In this study, we used an improved 2-D kinematic box model to assess the influence of these processes on diatom dynamics in an estuarine ecosystem affected by coastal upwelling. This model enabled us to separate hydrographic from biogeochemical processes occurring in the estuary. Hydrographic variables, nutrient concentrations and phytoplankton composition were determined over a 2 wk period in the Ría de Vigo, NW Spain. Two major hydrographic phases were identified which coincided with a clear temporal and spatial separation between 2 diatom assemblages: Thalassiosira spp./Skeletonema costatum and Chaetoceros spp./Cerataulina pelagica. During upwelling, horizontal $\left(6.6 \mathrm{~km} \mathrm{~d}^{-1}\right)$ and vertical $\left(11.7 \mathrm{~m} \mathrm{~d}^{-1}\right)$ convective fluxes were high, causing a net input of $\mathrm{NO}_{3}{ }^{-}, \mathrm{HPO}_{4}{ }^{2-}$ and $\mathrm{SiO}_{4} \mathrm{H}_{4}$. During this phase the Thalassiosira spp./ S. costatum standing stock was high $\left(>20 \mu \mathrm{mol} \mathrm{Cl}^{-1}\right)$. Hydrographic processes, however, affected the Thalassiosira spp./S. costatum assemblage more than biogeochemical processes and this resulted in the net loss of this assemblage from the Ría and its export towards the shelf. There was a significant correlation between the biogeochemical variations in this diatom assemblage and silicate, suggesting a strong dependency of Thalassiosira spp./S. costatum on this nutrient. By comparison, due to the higher carbon-specific net growth rate of the Chaetoceros spp./C. pelagica assemblage $\left(0.35 \mathrm{~d}^{-1}\right)$ during upwelling, this assemblage maintained a high biomass in the Ría. Upwelling was followed by upwelling relaxation when horizontal $\left(1.9 \mathrm{~km} \mathrm{~d}^{-1}\right)$ and vertical fluxes $\left(1.8 \mathrm{~m} \mathrm{~d}^{-1}\right)$ were reduced and nutrient levels diminished. During upwelling relaxation there was an accumulation of Chaetoceros

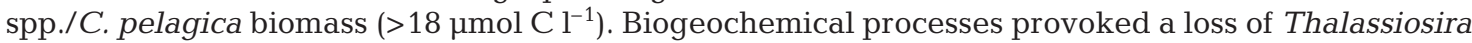
spp./S. costatum due to rapid sedimentation and a net increase in Chaetoceros spp./C. pelagica. It is suggested that the accumulation of Chaetoceros spp. is aided by a lower sinking rate whereas the selection of $C$. pelagica is more dependent on $\mathrm{NO}_{3}{ }^{-}$and $\mathrm{HPO}_{4}{ }^{2-}$ consumption. It is concluded that upwelling events in the Ría cause the exportation of Thalassiosira spp./S. costatum standing stock from the Ría towards the shelf, which will ultimately benefit shelf pelagic and benthic fish communities. Upwelling relaxation events favour the retention of a high standing stock of Chaetoceros spp./ C. pelagica, which is then directly available to the shellfish aquaculture of the Ría.
\end{abstract}

KEY WORDS: Diatom dynamics succession · Chaetoceros spp. $\cdot$ Cerataulina pelagica $\cdot$ Skeletonema costatum · Thalassiosira spp. · Standing stock · Upwelling · Estuarine ecosystems · 2-D box model circulation

Resale or republication not permitted without written consent of the publisher

\section{INTRODUCTION}

*Present address: Ecologie des Systèmes Aquatiques, Université Libre de Bruxelles, Campus de la Plaine CP 221, 1050 Brussels, Belgium

${ }^{* *}$ Corresponding author. E-mail: paco@iim.csic.es
Physical and chemical temporal variations in upwelling zones influence phytoplankton composition and succession (Blasco et al. 1980, Brink et al. 1980, 
Mann 1992). Physical and nutrient regimes are tightly coupled and it is often difficult to discern their individual effects on species successions and changes in biomass and primary production. Fluctuation in diatom composition and number has been correlated with changes in the circulation of water bodies associated with upwelling events (Huntsman \& Barber 1977, Margalef 1978, Barber \& Smith 1980, Jones \& Halpern 1981). The temporal evolution of upwelling to stratification is marked by a change from small-celled diatoms to a community of medium-sized mixed diatoms and culminates in flagellates which are better adapted at maintaining buoyancy under low mixing conditions (Smith et al. 1983, Mann 1993). Changes in nutrient regime are associated with upwelling/stratification cycles and have been correlated with species succession (e.g. Officer \& Ryther 1980). High nutrient inputs to the photic zone during upwelling coincide with high diatom biomass. Flagellates dominate under low phosphate and silicate and high ammonium concentrations during stratification (Legendre 1990). Diatom production contributes to the transfer of nitrogen from allochthonous nitrate to pools of both ammonium and dissolved organic nitrogen (DON), which selects for flagellate dominance (Álvarez-Salgado et al. 1996). Decreases in $\mathrm{Si} / \mathrm{N}$ and $\mathrm{Si} / \mathrm{P}$ ratios have also been attributed to the shift in dominance from diatoms to flagellates (Conley \& Malone 1992, Ragueneau et al. 1994). Each genera or species, due to its different nutrient requirements, has an optimum $\mathrm{Si} / \mathrm{N}$ and $\mathrm{P} / \mathrm{N}$ ratio for growth, and when environmental conditions are sustained long enough, there is succession towards the genera or species best adapted to the nutrient ratio in the photic zone (Tilman 1977). Within each stage of the succession from diatoms to flagellates, there exist short-term changes in diatom genera that are associated with specific hydrographic events and nutrient regimes (Margalef 1958). These short-term changes in the diatom assemblages are reflected in patterns of carbon fixation (Gallegos 1992, Lohrenz et al. 1994). Small diatoms such as Skeletonema costatum and Thalassiosira nana have high standing stock, growth rates and productivity and are typically associated with turbulent upwelled water. Medium-sized diatoms such as those of the genera Cerataulina, Chaetoceros, Lauderia, Coscinodiscus and Thalassionema have a lower productivity and growth rate and often succeed the smaller diatoms (Margalef 1958).

The spatial distribution of phytoplankton ultimately results from the interactions between physical processes such as convection and diffusion, and biological processes such as growth, mortality and predation, but it is difficult to evaluate which of these has the greatest influence on phytoplankton succession and variations in biomass and primary production. Little work has therefore been done on characterising the key fluxes associated with short-term changes in diatom communities. Recently, Painchaud et al. (1996) applied a 2-D circulation model to study the effects of biological (i.e. grazing and growth rates) and physical dispersion (i.e. advection and diffusion) processes on bacterial dynamics in St. Laurence Estuary, Quebec. The box model was used to generate residence times of hydrographic constituents in a particular volume of seawater and then used to assess the impact of these processes on the distribution of bacteria in the estuary. They found that biological processes had greater significance on the distribution of bacteria than physical ones. Boxmodel approaches provide more than just static descriptions of the processes in an estuary and are useful tools in analysing its dynamics. These types of models have been applied to the study of pollutants (Downing 1971), carbon (Prego 1993, Rosón et al. 1999) and nitrogen cycles (Álvarez-Salgado et al. 1996) and the effects of processes such as upwelling and recycling on inorganic and biogenic material (Shiller 1996). Few studies have applied box models to the study of phytoplankton dynamics. Chang \& Carpenter (1985) for example used a box model to show that Gyrodinium aureolum migrated to deeper waters of a Long Island estuary to maintain its position within the estuary. Figueiras et al. (1995) also used a box model to explain red tide development and evolution in the area of Rías Baixas.

Thalassiosira spp., Skeletonema costatum and Chaetoceros spp. are common in spring blooms in coastal regions as widespread as North America (Riebsell 1989), Northern Europe (Smetacek 1985), tropical Africa (Margalef 1972) and the southern ocean (Guillard \& Killam 1977). They co-occur in the same hydrodynamic features in upwelling zones (Hood et al. 1991, LopezJamar et al. 1992), bays and estuaries (Vives \& LopezBenito 1957, Waite et al. 1992, Tolomio et al. 1993, Tiselius \& Kuylenstierna 1996) and the open ocean (Tont \& Platt 1979, Kononen et al. 1992). These genera often dominate the diatom assemblage in upwelling zones, and blooms of Chaetoceros spp. coincide with high primary production found in some estuarine ecosystems affected by upwelling (e.g. Tilstone et al. 1999).

In this paper we study the significance of hydrodynamic processes on the selection and distribution of 2 diatom assemblages dominated by Chaetoceros spp./ Cerataulina pelagica and Thalassiosira spp./Skeletonema costatum in the Ría de Vigo, Spain. An improved 2-D box model of circulation based on that of Rosón et al. (1997) was utilised to study the relative importance of physical and biogeochemical processes on the shortterm selection of Thalassiosira spp./S. costatum and Chaetoceros spp./C. pelagica communities. Phytoplank- 
ton and nutrient fluxes were obtained from an empirical circulation model based on the thermohaline properties of the water column. The model was also used to assess the nutrient consumption by major diatom groups. The results are discussed in terms of the importance of hydrographic and biogeochemical processes on diatom selection, differences in nutrient consumption between diatoms and the exportation and retention of carbon in estuaries affected by upwelling.

\section{MATERIAL AND METHODS}

Study area. The Ría de Vigo forms part of the Rías Baixas, a series of flooded tectonic valleys located on the NW coast of Spain (Fig. 1). The Rías are reported to be the most productive zones in NW Spain due to nutrient enrichment through positive circulation and the upwelling of Eastern North Atlantic Central Water (ENACW). They have been classified as partially mixed estuaries (Dyer 1973, Beer 1983) with a positive circulation formed from 2 distinct layers (Fraga \& Margalef 1979) with a static layer between them (Fig. 2). The Ría de Vigo is the second largest of the Rías Baixas with a total length of $33 \mathrm{~km}$, a surface area of $176 \mathrm{~km}^{2}$ and volume of $3317 \mathrm{~km}^{3}$. The Ría represents an ecosystem where the typical 3 dimensional water transport of coastal upwelling is reduced to 2 dimensions and the effect of coastal along-shore transport is practically negligible (Villarino et al. 1995, Álvarez-Salgado et al. 1996). A 2-D kinematic box model can therefore be applied to the Rías with relative accuracy (e.g. Prego \& Fraga 1992). Winds that produce cross-shore transport on the coast (i.e. northerly \& southerly winds) have an indirect effect on Ría circulation by creating pressure gradients at the Ría mouth. Northerly winds result in coastal upwelling and cause an elevation of dense, sub-surface ENACW at the coast that moves into the Ría and enhances the positive estuarine circulation. By comparison, coastal downwelling is caused by southerly winds, which force ocean surface water into the Ría and produce a reversal of the estuarine circulation. Winds that produce along-shore water movement at the coast (i.e. easterly \& westerly winds) also influence water movement along the Ría axis (Chase 1975). Easterly winds move surface Ría water towards the ocean and therefore increase the

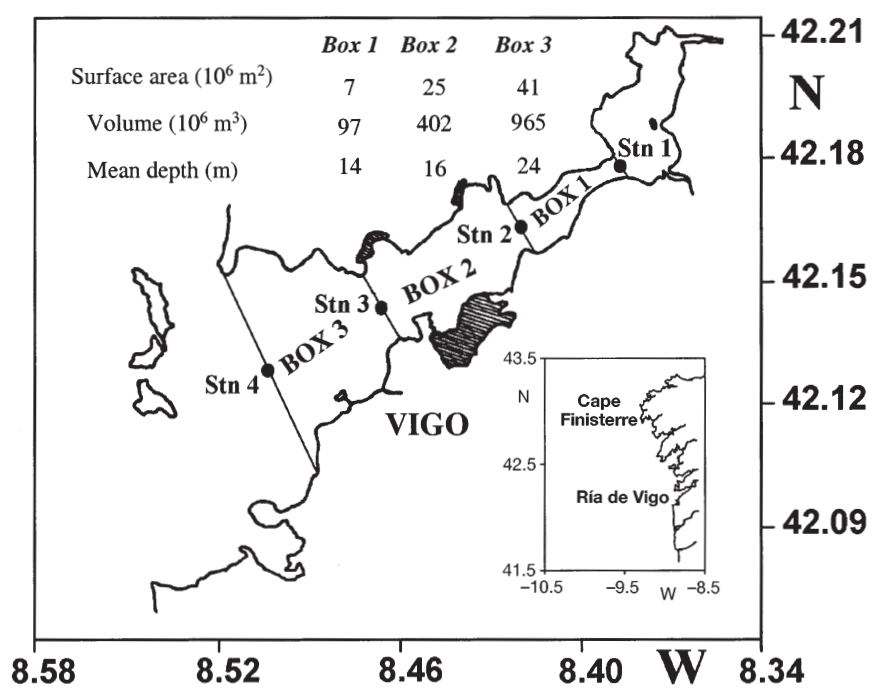

Fig. 1. Study area (northwest of the Iberian Peninsula) and sampling stations in the Ría de Vigo. Box dimensions for the model are also given

positive estuarine circulation in a way similar to that of northerly winds. By comparison, westerly winds can move oceanic surface water into the Ría interior, which causes a reversal of the estuarine circulation;

\section{Atmosphere}

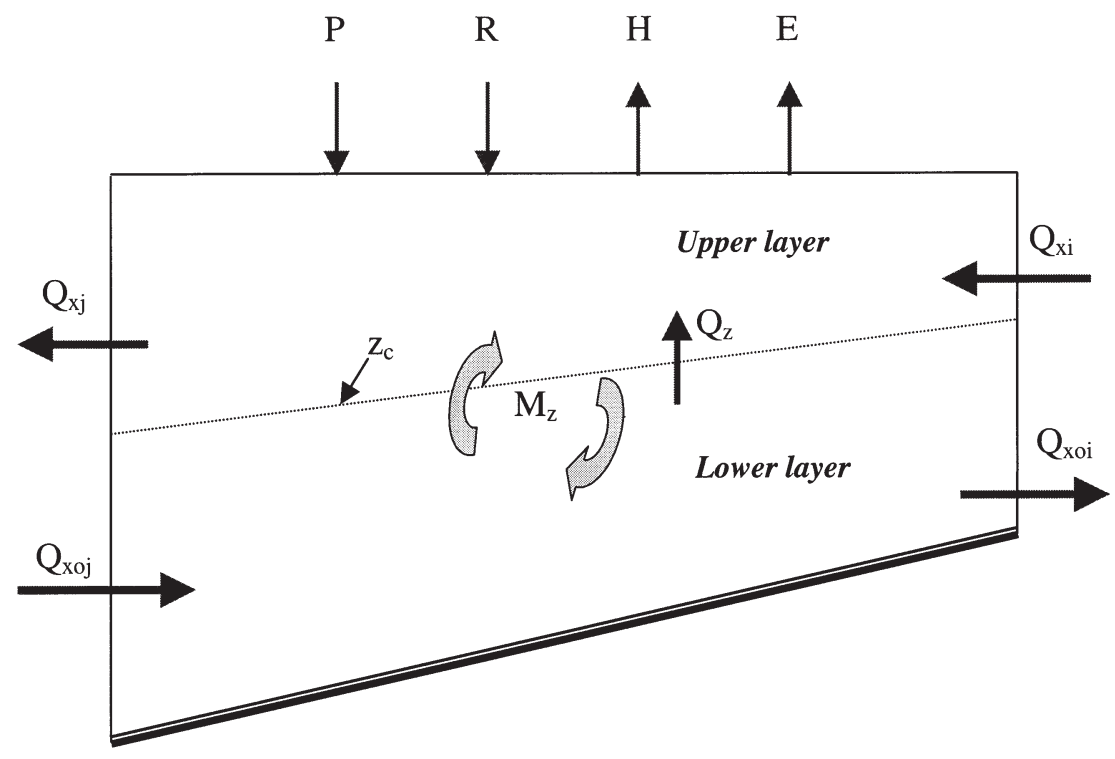

Fig. 2. Notation for fluxes across borders of a generic box segmented into 2 layers. $Q_{x i}$ and $Q_{x j}$ are inward and outward horizontal convective flows to the upper layer; $Q_{X 0 i}$ and $Q_{x 0 j}$ outward and inward horizontal convective flows to the lower layer; $Q_{Z}$ is the upward convective flow from the lower to the upper layer; $M_{z}$ is vertical turbulent diffusive flow; $P$ : precipitation; $E$ : Evaporation; $R$ : continental runoff $H_{i} H$ : Heat exchange with the atmosphere $z_{C}$ is the no motion level 
the Ría water flows to the ocean via deeper circulation currents and downwelling occurs.

Hydrography. Samples were taken from 4 stations in the Ría de Vigo (Fig. 1) aboard the 'Lampadena' for 6 d over a 2 wk period from 9 to 24 March 1994. Each station was initially sampled using a conductivity-temperature-depth sampler (CTD Sea Bird 25) fitted with a 'Sea Tech' fluorometer. Using the fluorescence profiles obtained from a single CTD cast, maximum fluoresence peaks were used to determine sampling depths for a more detailed analysis of the biological characteristics of the Ría. Seawater samples were then collected at 4 to 5 depths in the water column, with 2 or 3 samples located near to the fluoresence maximum, using 51 Niskin bottles fitted with reversing thermometers. Aliquots were taken from the Niskin bottles and frozen immediately for the analysis of nutrients in the laboratory using a Technicon AAII SFA auto analyser. The reduction method to nitrites in a $\mathrm{Cd}-\mathrm{Cu}$ column was used to determine nitrate (Mouriño \& Fraga 1985). Silicic acid and phosphates were analysed using the method of Hansen \& Grasshoff (1983) with some modifications by Álvarez-Salgado et al. (1992). Conductivity was measured using an autosal 8400A salinometer calibrated with standard seawater and salinity was then calculated using the UNESCO (1983) equation. A sub-sample of $100 \mathrm{ml}$ of seawater from each depth was filtered through a $2.5 \mathrm{~cm}$ Whatman GF/F filter, and chlorophyll a ( $\mathrm{chl} \mathrm{a}$ ) values were then determined by fluorometry using a Turner fluorometer Model 10000 R (Yentsch \& Menzel 1963).

The magnitude and direction of the wind at Cape Finisterre $\left(43^{\circ} \mathrm{N}, 11^{\circ} \mathrm{W}\right)$ were deduced from surface pressure charts $\left(3\right.$ times $\left.\mathrm{d}^{-1}\right)$ and were used to calculate the Ekman transport parallel and perpendicular to the coast. The cross-shore and along-shore transport calculated at Cape Finisterre are considered representative of the general conditions for the whole of the west coast of Galicia, including the Rías Baixas (Blanton et al. 1984, Lavin et al. 1991). Wind speed at the sea surface was estimated by multiplying wind vectors by 0.7 and cyclonically rotating them by $15^{\circ}$ to correct for frictional forces. Wind stress was calculated using the equation of Bakun (1973):

$$
\tau_{x, y}=\rho_{\mathrm{a}} C_{\mathrm{d}}|V| V_{x, y}
$$

where $\tau_{x, y}$ is the stress vector, $\rho_{a}$ is the air density $\left(1.22 \mathrm{~kg} \mathrm{~m}^{-3}\right), C_{\mathrm{d}}$ is the empirical drag coefficient $(1.3 \times$ $10^{-3}$, according to Hidy 1972), and $V_{x, y}$ is the vector corresponding to the estimated wind speed on the sea surface, with magnitude $|V|$. The Ekman transport component, cross-shore transport $\left(q_{x}\right)$, and alongshore transport $\left(q_{y}\right)$ were obtained by dividing $\tau_{x, y}$ by the Coriolis parameter $f\left(9.946 \times 10^{-5} \mathrm{~s}^{-1}\right)$ and by the density of seawater $\left(\rho_{\mathrm{w}} \sim 1025 \mathrm{~kg} \mathrm{~m}^{-3}\right)$; thus:

$$
q_{x, y}=\frac{\rho_{\mathrm{a}} C_{\mathrm{d}}|V| V_{X, Y}}{f \rho_{\mathrm{w}}}
$$

Microplankton identification and carbon content. Microplankton samples were preserved in Lugol's iodine and sedimented in $50 \mathrm{ml}$ composite sedimentation chambers. Diatoms, dinoflagellates, flagellates and ciliates (oligotrichous and peritrichous) were identified and counted to the species level (where possible) using single transects at $\times 250$ and $\times 400$ for small species and a scan of the whole slide at $\times 100$ for larger species (Utermöhl 1958). A principal component analysis (PCA) based on a correlation matrix of abundances was used to determine the main microplankton assemblages. Species abundances were transformed to log $(x+1)$, where $x$ represents the number of individuals $\mathrm{ml}^{-1}$ of seawater. Double zeros in the PCA matrix were reduced by eliminating species that were not present in at least $20 \%$ of the samples (Legendre \& Legendre 1983); thus PCA was performed on 103 samples and 58 microplankton species.

The dimensions of each autotrophic phytoplankton species identified were measured and cell volumes were determined by approximation to the nearest geometric shape (Edler 1979). The plasma volume of diatoms and biovolume of flagellates, dinoflagellates and Mesodinium rubrum were converted to carbon contents using the conversion factor of Strathmann (1967) as follows:

Diatoms

$$
\log _{10} C=0.892\left(\log _{10} V P\right)-0.61
$$

Flagellates, dinoflagellates and Mesodinium rubrum

$$
\log _{10} C=0.866\left(\log _{10} V\right)-0.46
$$

in which $V P$ represents the plasmatic volume $\left(\mu \mathrm{m}^{3} \mathrm{cell}^{-1}\right), V$ is the total cell volume $\left(\mu \mathrm{m}^{3} \mathrm{cell}^{-1}\right)$ and $C$ is the quantity of cell carbon $(\mathrm{pg} \mathrm{C}$ cell-1).

Box model of residual circulation, phytoplankton and nutrient dynamics. An improved 2-D kinematic non-steady-state box model was used to characterise the residual circulation in the Ría and then to assess the influence of hydrographic and biogeochemical components on nutrient and phytoplankton dynamics. The box model eliminates gross inputs and outputs of a single factor in each box by characterising the fluxes due to hydrographic and biogeochemical processes and provides us with an estimate of the net gains or losses of a specific factor in each box.

Residual circulation. Fluxes were derived from the salinity and temperature profiles using a 2-D non-steadystate box model, which is extensively described by Rosón et al. (1997) for a similar coastal system in the zone. 
The study area was divided into 3 adjacent boxes (Fig. 1). The sampling stations were located in the boundary walls of each box. The volume of a single box is assumed to remain constant $\left(\mathrm{d} V_{\mathrm{B}} / \mathrm{d} t=0\right)$ over time scales greater than 1 tidal cycle which implies that the net water budget must be zero. The terms included in the water budget are continental runoff $(R)$, precipitation $(P)$, evaporation $(E)$ and the sum of horizontal residual flows $\left(Q_{x i}\right)$ exchanging across the borders of each box (all terms in $\mathrm{m}^{3} \mathrm{~s}^{-1}$ ) and the following relationship can be described for time-dependent changes in volume:

$$
\frac{\mathrm{d} V_{\mathrm{B}}}{\mathrm{d} t}=R+P-E+\sum_{i} Q_{X i}=0
$$

For budgets of conservative properties such as salinity and temperature it is possible to write a similar equation based on the hypothesis that changes of the properties inside a box will be due to exchanges across its border. Unlike total volume $V_{\mathrm{B}}$, the new property $N_{\mathrm{B}}$ does change with the time $\left(\mathrm{d} N_{\mathrm{B}} / \mathrm{d} t \neq 0\right.$; non-steadystate model) thus,

$$
V_{\mathrm{B}} \cdot \frac{\mathrm{d} N_{\mathrm{B}}}{\mathrm{d} t}=R \cdot N_{R}+P \cdot N_{P}-E \cdot N_{E}+\sum_{i} Q_{x i} \cdot N_{Q}
$$

where $N_{R}, N_{P}, N_{E}, N_{Q}$ are averaged salinity or temperature in each of the flows included in the budget.

On the basis of a 2 layered circulation pattern, each box was segmented into 2 layers separated by a zerovelocity level $\left(z_{\mathrm{c}}\right)$ which was fixed at the pycnocline where mixing is inhibited. A general presentation of the terms for the 2 layers of each box is shown in Fig. 2.

Eq. (6) varies depending on the property we consider (e.g. in the case of temperature, heat exchange with the atmosphere, $H$, must also be included). When calculating budgets inside the layers, vertical flows $\left(Q_{Z}\right.$, $M_{z}$ ) must also be taken into consideration.

The model uses 2 sets of linear equations (one for salinity and one for temperature). The unknown $Q_{X i}$ can be calculated from the total freshwater flow input to each box (including runoff and evaporation-rainfall balance), the heat exchange between the ocean and the atmosphere, the average concentration of a property in the walls, box or layers, and the time variation of the thermohaline properties.

Rainfall data were taken from the Meteorological Observatory at Vigo Airport and corrected according to altitude above the sea level. Evaporation was obtained from an empirical relationship based on wind velocity and vapour pressure (Otto 1975, Rosón et al. 1997). Runoff was calculated according to Ríos et al. (1992) using rainfall in the drainage basin. Heat exchange was calculated as the sum of the irradiation, atmospheric and oceanic back radiation and conduction, and reflection terms as per Rosón et al. (1997).
Mean values of salinity and temperature were obtained from vertical CTD profiles, which were averaged using the geometric characteristics of each box. The errors involved in the measurement of all variables were used to estimate the accuracy of the flux calculation. Assuming an analytical error of $10 \%$ for $H$, $R, P$ and $E, \pm 0.005$ psu for salinity and $\pm 0.005^{\circ} \mathrm{C}$ for temperature, there would be an overall error of $7 \%$ for horizontal convective flows, $12 \%$ for vertical convective flows and $22 \%$ for vertical diffusive flows.

A steady-state condition is normally used to quantify the non-wind forced changes in hydrography and biogeochemistry between sampling periods (Officer 1980). Upwelling results in non-steady state conditions however, so that the sampling frequency has to be sufficiently frequent to monitor the changes between each data collection. Sampling was therefore undertaken every 2 to $3 \mathrm{~d}$.

Time variations of $N_{\mathrm{B}}$ (salinity or temperature) in a single box for a given day $t_{n}$ can be expressed as an average increment between the previous sampling day, $t_{n-1}$, the present sampling day, $t_{n}$ and the following sampling day, $t_{n+1}$.

$$
\frac{\mathrm{d} N_{\mathrm{B}}}{\mathrm{d} t}=\frac{1}{2}\left(\frac{N_{\mathrm{B} t_{n}}-N_{\mathrm{B} t_{n-1}}}{t_{n}-t_{n-1}}+\frac{N_{\mathrm{B} t_{n+1}}-N_{\mathrm{B} t_{n}}}{t_{n+1}-t_{n}}\right)
$$

Therefore, Eq. (7) yields $\mathrm{d} N_{\mathrm{B}} / \mathrm{d} t$ data for the 4 periods between the 6 sampling days.

Phytoplankton and nutrient dynamics. Unlike conservative properties, when dealing with budgets of phytoplankton or nutrients we must take into account the biogeochemical processes which occur within the boxes. For phytoplankton and nutrients, $\mathrm{d} N_{\mathrm{B}} / \mathrm{d} t$ as given in Eq. (6) now becomes the sum of a hydrographic component, $\delta N_{H}$, and a biogeochemical one, $\delta N_{B G}$ :

$$
\frac{\mathrm{d} N_{\mathrm{B}}}{\mathrm{d} t}=\delta N_{H}+\delta N_{B G}
$$

Using Eq. (6) we can estimate the total hydrographic component that can be applied to the transport of nutrients and phytoplankton associated with the residual circulation by replacing ' $N$ ' terms with corresponding nutrients or phytoplankton concentration. Evaporation and rainfall are not included in the estimation of $\delta N_{H}$ since the concentration of either phytoplankton or nutrients carried by these flows is negligible; hence:

$$
\delta N_{H}=\frac{1}{V_{\mathrm{B}}} \cdot\left(R \cdot N_{R}+\sum_{i} Q_{x i} \cdot N_{Q}\right)
$$

Once we obtain the hydrographic component $\left(\delta N_{H}\right)$ using Eq. (9) and the net temporal change $\mathrm{d} N_{\mathrm{B}} / \mathrm{d} t$ using Eq. (7), the rate of change due to biogeochemical processes $\left(\delta N_{B G}\right)$ can be derived simply by subtracting them: 


$$
\delta N_{B G}=\frac{\mathrm{d} N_{\mathrm{B}}}{\mathrm{d} t}-\delta N_{H}
$$

The variation in biomass of phytoplankton due to non-hydrographic processes $\delta N_{B G}$ is comprised of growth and any other biological property that permits phytoplankton to remain in the water column such as swimming and buoyancy (inputs), grazing and removal from the water column due to mortality and sinking (outputs). In terms of nutrient changes, $\delta N_{B G}$ represents the net balance between nutrient re-mineralisation and nutrient uptake. In terms of phytoplankton a $\delta N_{H}<0$ result indicates net loss or export from a particular box. $\delta N_{H}+\delta N_{B G}>0$ indicates a net accumulation and the positive selection of a phytoplankton assemblage within a box. $\mathrm{d} N_{\mathrm{B}} / \mathrm{d} t$ indicates the instantaneous rate of change.

The overall errors in the estimation of $\delta N_{H}$ and $\delta N_{B G}$ during the study period were evaluated using the analytical error in the determination of nutrients (ÁlvarezSalgado et al. 1996) and phytoplankton and the errors associated with the fluxes. $\delta N_{H}$ incurrs a total error of $6 \%$ for $\mathrm{NO}_{3}{ }^{-}, 10 \%$ for $\mathrm{HPO}_{4}{ }^{2-}$ and $6 \%$ for $\mathrm{SiO}_{4} \mathrm{H}_{4}$. The corresponding errors in the determination of $\delta N_{B G}$ are: $10 \%$ for $\mathrm{NO}_{3}{ }^{-}, 18 \%$ for $\mathrm{HPO}_{4}{ }^{2-}$ and $8 \%$ for $\mathrm{SiO}_{4} \mathrm{H}_{4}$. The accuracy in the identification and counting of phytoplankton species cannot be objectively evaluated. We therefore used random errors of 5, 10 and $20 \%$ and tested their effect on the errors associated with $\delta N_{H}$ and $\delta N_{B G}$. For the assemblages considered in this work (i.e. Thalassiosira spp./Skeletonema costatum and Chaetoceros spp./Cerataulina pelagica), the mean overall error varied between 11 and $42 \%$ for $\delta N_{H}$, and between 10 and $65 \%$ for $\delta N_{B G}$.

Stepwise multiple regression of the biogeochemical variation in each nutrient and the biogeochemical change in biomass of major diatom groups (Cerataulina pelagica, Chaetoceros spp., Coscinodiscus spp., RhizosoleniaGuinardia spp., Skeletonema costatum, Thalassiosira spp. and other diatoms) in the upper layer of the 3 boxes was used to assess the dependence of major diatom groups on nutrient consumption.

\section{RESULTS}

\section{Meteorological and hydrographic conditions}

Ekman transport components and the magnitude of the geostrophic wind vector for the sampling period from 6 to 24 March 1994 are given in Fig. 3. On 6 March there was an upwelling event followed by upwelling relaxation-weak downwelling between 6 to 9 March, which was initiated by the relaxation of northeasterly winds and a change to southwesterly winds on 9 March (Fig. 3). This introduced relatively warmer, more saline, coastal water into the Ría (Fig. 4). After 9 March the winds changed back to the northeast (Fig. 3), which caused upwelling. Upwelling was detected in the Ría from 11 to 14 March and can be seen from the gradual intrusion at bottom layers of colder, more saline water (Fig. 4). From 11 to 15 March a decay in wind strength caused a decrease in the $q_{x}$ and $q_{y}$ Ekman transport components (Fig. 3) and upwelling relaxation occurred along the Galician coast. This was recorded in the Ría on 16 March by the downward displacement of the $12.8^{\circ} \mathrm{C}$ (temperature) and 35.6 (salinity) isolines (Fig. 4). A slight increase followed by decrease in $q_{x}$ and $q_{y}$ from 15 to 24 March (Fig. 3) indicated cycles of light upwelling and upwelling relaxation along the coast, which was detected in the Ría from 16 to 22 March by thermohaline stratification (Fig. 4).

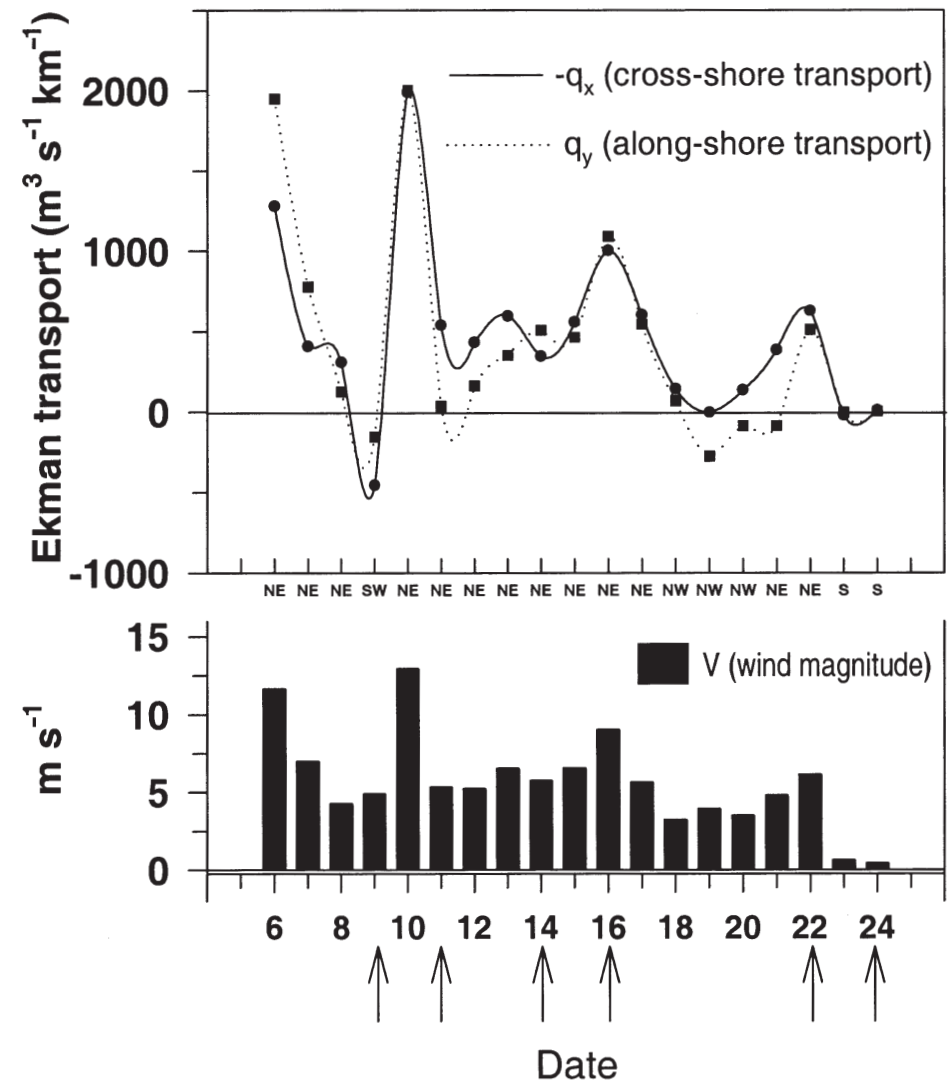

Fig. 3. Ekman transport components calculated at $43^{\circ} \mathrm{N}, 11^{\circ} \mathrm{W}$ and magnitude of the wind for the sampling period from 6 to 24 March 1994. Arrows indicate sampling dates 

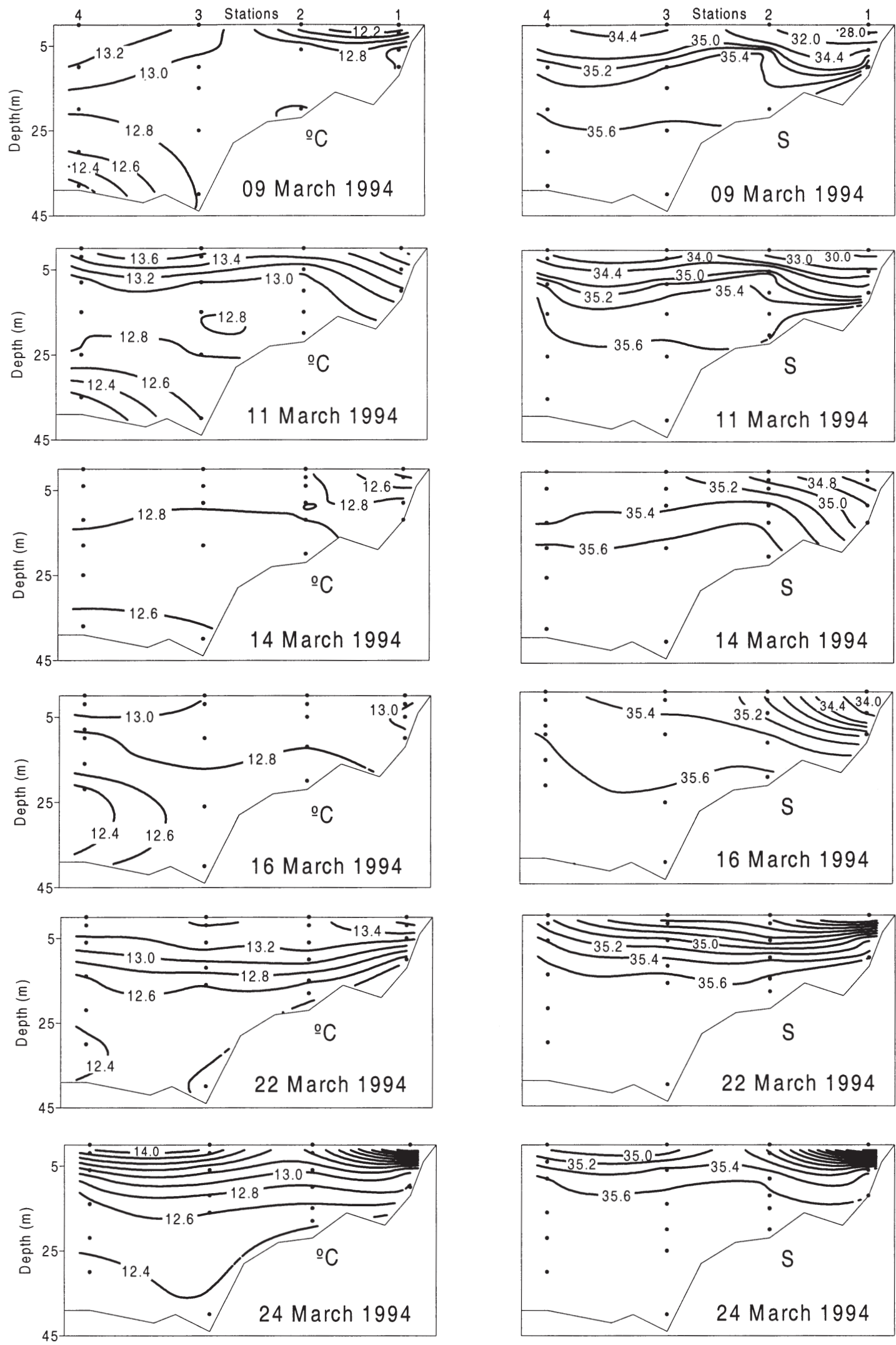

Fig. 4. Temperature $\left({ }^{\circ} \mathrm{C}\right)$ and salinity (S) distributions in the Ría de Vigo from 9 to 24 March 1994 


\section{Nutrients}

On 9 March 1994, during the first upwelling relaxation, $\mathrm{NO}_{3}{ }^{-}, \mathrm{HPO}_{4}{ }^{2-}$ and $\mathrm{SiO}_{4} \mathrm{H}_{4}$ levels were relatively high $\left(5,0.4\right.$ and $4 \mu \mathrm{mol} \mathrm{kg}{ }^{-1}$ respectively; Figs. $5 \& 6$ ) due to the re-introduction of previously upwelled water into the Ría. Nutrient levels were reduced on 11 March indicating consumption by phytoplankton. The appearance at bottom layers of 10, 0.6 and $4 \mu \mathrm{mol} \mathrm{kg} \mathrm{kg}^{-1}$ for $\mathrm{NO}_{3}{ }^{-}, \mathrm{HPO}_{4}{ }^{2-}$ and $\mathrm{SiO}_{4} \mathrm{H}_{4}$ isolines respectively on 14 March corresponds to upwelling in the Ría, which incremented nutrient levels in the photic zone. Variation in nutrient concentrations were low from 16 March onwards (Figs. $5 \& 6$ ) when some evidence of $\mathrm{HPO}_{4}{ }^{2-}$ and $\mathrm{SiO}_{4} \mathrm{H}_{4}$ consumption by phytoplankton throughout the photic zone existed.

\section{Chlorophyll a, microplankton communities and biomass}

At the beginning of March 1994, chl a levels were low in surface layers (1.0 $\mathrm{mg} \mathrm{m}^{-3}$; Fig. 6). During upwelling from 11 to 14 March, chl a levels increased (max; $11 \mathrm{mg} \mathrm{m}^{-3}$ at Stn 3; Fig. 6), but then decreased during the relaxation event of 16 March. From 22 to 24 March during water column stratification there was again an increase in chl a (12 $\mathrm{mg} \mathrm{m}^{-3}$; Fig. 6), which shifted from the middle of the Ría towards the interior.

The first 2 principal components of the principal component analysis on the microplankton assemblage explained $39.85 \%$ of the total variance. The first principal component (PC 1) explained $21.03 \%$, the second (PC 2) explained $8.82 \%$. Diatoms represented $83 \%$ of the total cell abundance; $9.15 \%$ were small flagellates and $6.32 \%$ dinoflagellates. PC 1 showed differences in abundance in a community of diatoms which consisted mainly of Chaetoceros spp., Cerataulinia pelagica and Rhizosolenia setigera (Table 1, positive loads), which is characteristic of the spring bloom in the Rías (Figueiras \& Neill 1987). Less than $50 \%$ of the PC 1 species had negative loads and the correlation between log (total cell abundance) and PC 1 scores was high $\left(\mathrm{r}^{2}=0.68\right.$; $\mathrm{p}<0.001$ ), which indicates that this component was related to total cell abundance. PC 2 showed differences in abundance between 2 communities dominated by Thalassiosira spp. and Skeletonema costatum (positive loads) and Chaetoceros spp., Gymnodinium catenatum and Strombidium sulcatum (negative loads; see Table 1).

Fig. 7 illustrates the distributions of the phytoplankton communities characterised by PC 1 and PC 2 in the Ría. On the first day of sampling, during the first upwelling relaxation event, PC 1 positive scores were only observed in the surface layer of the interior of the Ría (Fig. 7). On 11 and 14 March during upwelling the
Table 1. Correlation coefficients of the species selected for principal component analysis (PCA) with the first 2 principal components. Species are ordered according to PC 1. The higher positive loads for PC 2 are given in bold

\begin{tabular}{|c|c|c|}
\hline Taxon & PC 1 & PC 2 \\
\hline Chaetoceros didymus & 0.868 & 0.012 \\
\hline Chaetoceros socialis & 0.843 & 0.132 \\
\hline Chaetoceros curvisetus & 0.836 & 0.307 \\
\hline Cerataulina pelagica & 0.832 & 0.007 \\
\hline Rhizosolenia setigera & 0.761 & 0.346 \\
\hline Chaetoceros lorezianus & 0.737 & 0.025 \\
\hline Chaetoceros affinis & 0.709 & 0.028 \\
\hline Gyrodinium spirale & 0.706 & 0.152 \\
\hline Strombidium cornucopiae & 0.705 & -0.131 \\
\hline Detonula pumila & 0.671 & -0.004 \\
\hline Gyrodinium falcatum & 0.619 & 0.153 \\
\hline Diplopsalis lenticula & 0.618 & -0.089 \\
\hline Guinardia delicatula & 0.597 & -0.164 \\
\hline Asterionellopsis glacilis & 0.593 & -0.064 \\
\hline Gymnodinium varians & 0.582 & -0.159 \\
\hline Ditylum brightwellii & 0.578 & 0.364 \\
\hline Chaetoceros compressus & 0.569 & -0.057 \\
\hline Gyrodinium fusiforme & 0.558 & -0.015 \\
\hline Gymnodinium catenatum & 0.538 & -0.185 \\
\hline Thalassiosira rotula & 0.516 & 0.440 \\
\hline Chaetoceros debilis & 0.487 & 0.466 \\
\hline Scrippsiella trochoidea & 0.471 & 0.173 \\
\hline Cryptophycea spp. & 0.440 & 0.117 \\
\hline Mesodinium rubrum & 0.423 & 0.238 \\
\hline Chaetoceros diadema & 0.422 & -0.449 \\
\hline Lohmaniella spiralis & 0.410 & -0.040 \\
\hline Amphidinium flagellans & 0.399 & -0.155 \\
\hline Strombidium conicum & 0.370 & -0.123 \\
\hline Auxospores & 0.324 & 0.034 \\
\hline Prorocentrum micans & 0.285 & 0.197 \\
\hline Protoperidinium bipes & 0.197 & 0.031 \\
\hline Oxytoxum sceptrum & 0.197 & -0.100 \\
\hline Strombidium sulcatum & 0.193 & -0.180 \\
\hline Strombidium cornutum & 0.188 & 0.314 \\
\hline Cocconeis scutellum & 0.143 & 0.526 \\
\hline Torodinium robustum & 0.129 & -0.010 \\
\hline Eutreptiella sp. & 0.114 & 0.456 \\
\hline Scrippsiella faeroense & 0.079 & 0.173 \\
\hline Pinnularia spp. & 0.079 & -0.087 \\
\hline Chaetoceros laciniosus & 0.079 & 0.580 \\
\hline Heterocapsa niei & 0.073 & -0.173 \\
\hline Prorocentrum minimum & 0.005 & 0.129 \\
\hline Strombidium turbo & -0.023 & 0.166 \\
\hline Gymnodinium simplex & -0.063 & 0.104 \\
\hline Gymnodinium nanum & -0.100 & 0.097 \\
\hline Thalassiosira nana & -0.129 & 0.624 \\
\hline Thalassionema nitzschioides & -0.149 & 0.446 \\
\hline Cysts & -0.154 & -0.120 \\
\hline Thalassiosira decipiens & -0.180 & 0.749 \\
\hline Tintinopsis beroidea & -0.195 & 0.464 \\
\hline Navicula sp. & -0.197 & 0.018 \\
\hline Gymnodinium hamulus & -0.211 & 0.183 \\
\hline Nitzschia longissima & -0.220 & 0.221 \\
\hline Skeletonema costatum & -0.305 & 0.709 \\
\hline Thalassiosira nordenskioldii & -0.320 & 0.762 \\
\hline Gymnodinium agiliforme & -0.323 & 0.156 \\
\hline Unidentified small flagellates & -0.417 & 0.295 \\
\hline Melosira sulcata & -0.545 & 0.142 \\
\hline
\end{tabular}



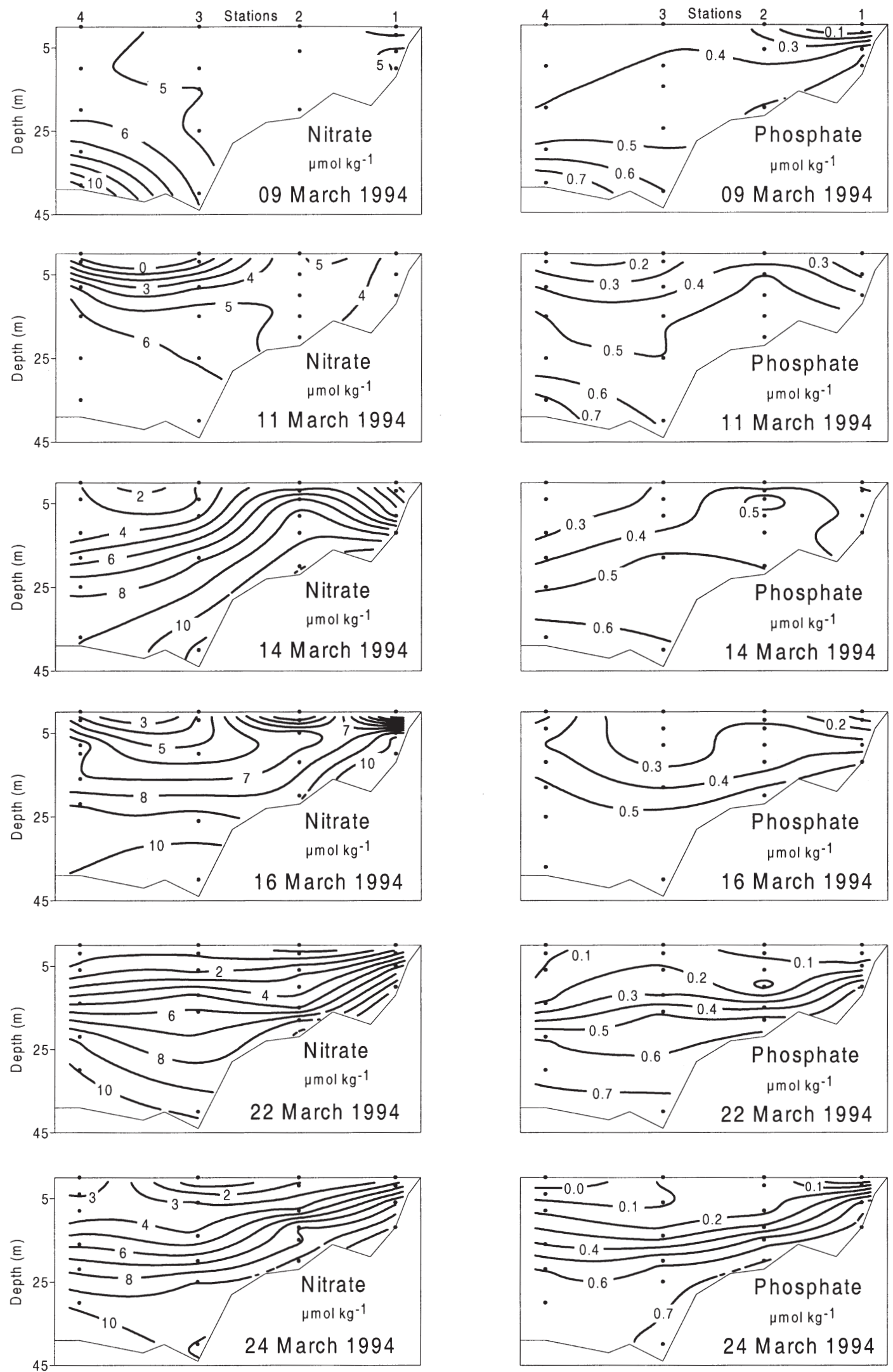

Fig. 5. Nitrate $\left(\mu \mathrm{mol} \mathrm{kg}{ }^{-1}\right)$ and phosphate $\left(\mu \mathrm{mol} \mathrm{kg}^{-1}\right)$ distributions in the Ría de Vigo from 9 to 24 March 1994 

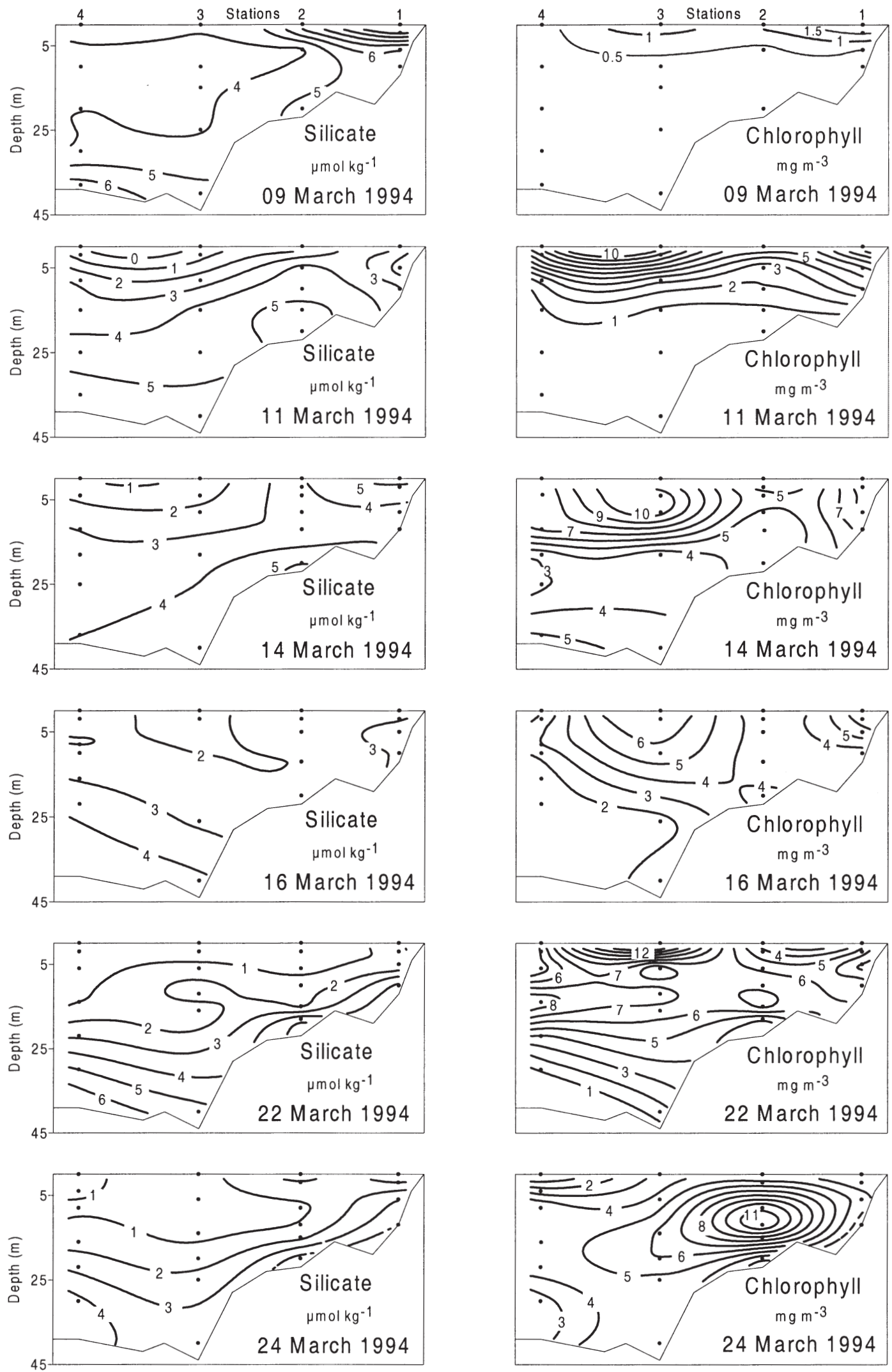

Fig. 6. Silicic acid $\left(\mu \mathrm{mol} \mathrm{kg}{ }^{-1}\right)$ and chlorophyll a $\left(\mathrm{mg} \mathrm{m}^{-3}\right)$ distributions in the Ría de Vigo from 9 to 24 March 1994 

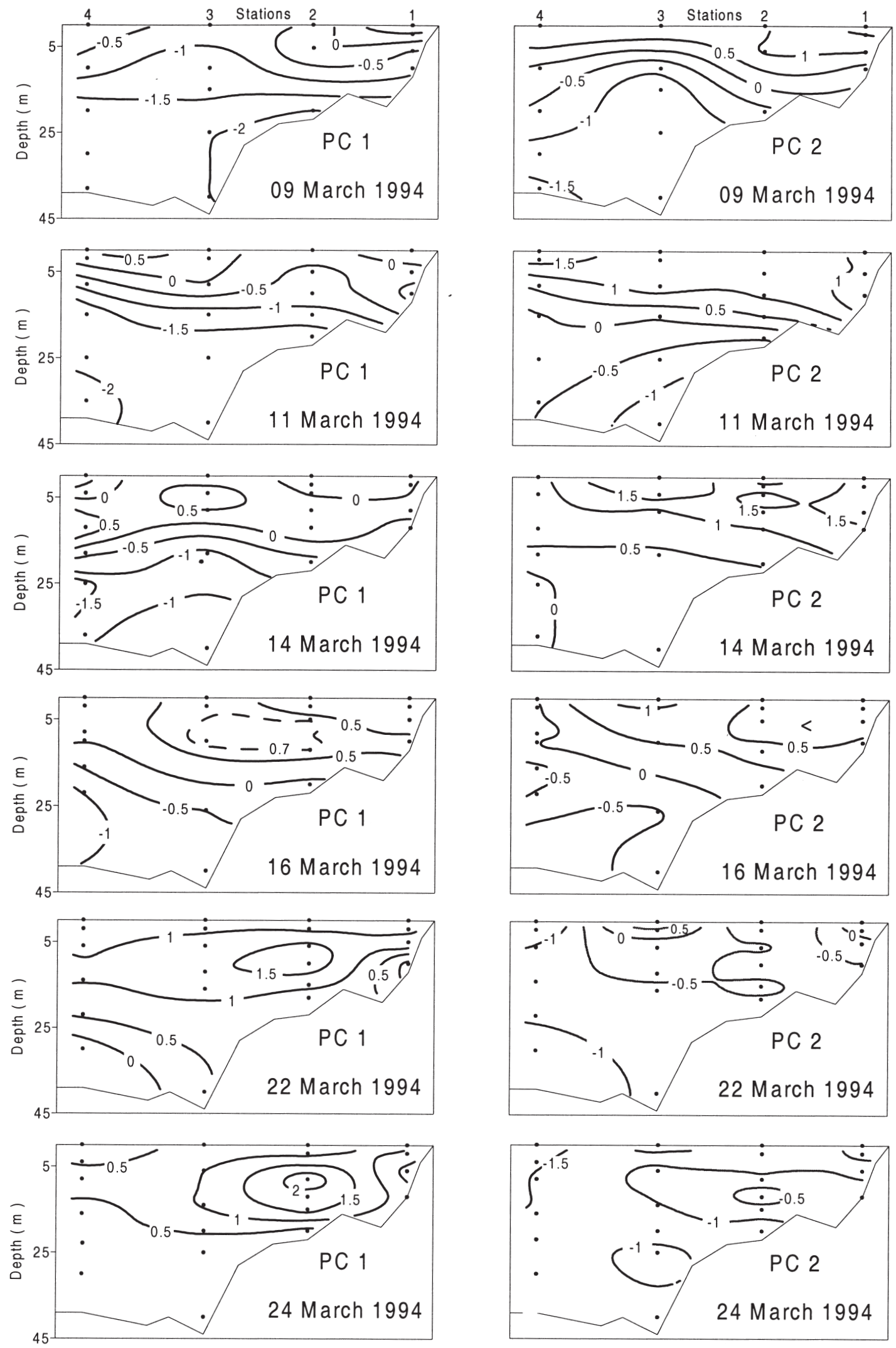

Fig. 7. Distribution of phytoplankton species PC 1 and PC 2 scores for the sampling period 9 to 24 March 1994 
Chaetoceros spp./Cerataulina/Rhizosolenia community was carried towards the mouth of the Ría as upwelled subsurface water moved outwards. From 16 to 24 March upwelling relaxation was followed by light upwelling and stratification, and the Chaetoceros spp./ Cerataulina/Rhizosolenia community gradually became more and more abundant throughout the Ría with a maximum at Stn 2. On 9 March after the first upwelling relaxation event the Thalassiosira spp./Skeletonema costatum community, characterised by PC 2 positive scores, was more abundant in the surface layers of the interior of the Ría (Fig. 7). From 11 to 14 March during the period of upwelling, this community became more abundant throughout the whole of the Ría (Fig. 7). During the second upwelling relaxation from 16 to 22 March the abundance of the Thalassiosira spp./S. costatum community diminished until it had completely disappeared by 24 March (Fig. 7).

The total cell carbon content of the Chaetoceros spp./Cerataulina pelagica and Thalassiosira spp./Skeletonema costatum assemblages are given in Fig. 8. Following the relaxation event on 9 March, the standing stock of Thalassiosira spp./S. costatum was high and accounted for $35 \%$ of the total autotrophic microplankton biomass in the Ría. By comparison, Chaetoceros spp./C. pelagica constituted only $5 \%$ (Fig. 8). During upwelling from 11 to 14 March Thalassiosira spp./ S. costatum biomass increased accounting for $>60 \%$ of the total biomass, with a maximum at Stn 3 on 11 March (20 $\mathrm{mol} \mathrm{C}^{-1}$; Fig. 8). The total carbon content of Chaetoceros spp./C. pelagica was comparatively lower

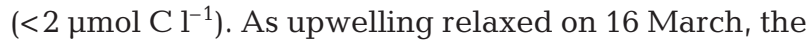
total carbon content of Thalassiosira spp./S. costatum diminished to $37 \%$ of the total carbon biomass. The standing stock of Chaetoceros spp./C. pelagica increased from 16 to 24 March during a period of water column stratification and reached a maximum on 24

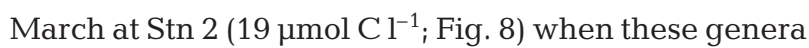
accounted for $73 \%$ of the total biomass in the Ría. Thalassiosira spp./S. costatum total carbon remained low $\left(<2 \mu \mathrm{mol} \mathrm{C} \mathrm{l}^{-1}\right.$; Fig. 8) and constituted only $9 \%$ of the total. Differences in carbon biomass between each diatom assemblage, on each sampling day, were analysed using a 2-tailed Student's $t$-test. Chaetoceros spp./C. pelagica had a significantly higher biomass than the Thalassiosira spp./S. costatum community on 22 March $\left(t_{1,17}=5.86, \mathrm{p}<0.001\right)$ and 24 March $\left(t_{1,18}=5.42\right.$, $\mathrm{p}<0.001)$. The biomass of Thalassiosira spp./S. costatum was significantly higher than Chaetoceros spp./ C. pelagica on $11\left(t_{1,17}=3.27, \mathrm{p}=0.004\right)$ and 14 March $\left(t_{1,17}=5.78, \mathrm{p}<0.001\right)$. During the 2 upwelling relax- ations on 9 and 16 March there were no significant differences in biomass between the 2 assemblages.

\section{Box model of residual circulation, phytoplankton and nutrient dynamics}

Residual circulation

Horizontal convective residual fluxes for each wall of the 3 boxes are given in Table 2. $Q_{X}$ and $Q_{x 0}$ represent the horizontal fluxes of surface and sub-surface water respectively. The highest horizontal residual fluxes and velocities in the Ría were observed on 14 March (mean velocity for the surface layer of the Ría, $\left.6.6 \mathrm{~km} \mathrm{~d}^{-1}\right)$, which is indicative of upwelling. The lowest values were found on 22 March (mean velocity for the surface layer of the Ría, $1.9 \mathrm{~km} \mathrm{~d}^{-1}$ ) during upwelling relaxation and stratification. On 16 March during the transition from upwelling to relaxation the horizontal flux decreased (mean velocity for the surface layer of the Ría, $3.6 \mathrm{~km} \mathrm{~d}^{-1}$ ).

The vertical convective and diffusive fluxes $\left(Q_{z}, M_{z}\right)$, for the 3 boxes are given in Table 3. High vertical

Table 3. Vertical convective $Q_{z \prime}$ and turbulent diffusive $M_{z \prime}$ residual fluxes of water $\left(\mathrm{m}^{3} \mathrm{~s}^{-1}\right)$ between the upper and lower layer of the 3 boxes. Arrows indicate the direction of the fluxes. Corresponding velocities $\left(\mathrm{m} \mathrm{d}^{-1}\right)$ are given in parentheses

\begin{tabular}{|c|c|c|c|c|c|}
\hline Day & Box 1 & Box 2 & Box 3 & Flux & \\
\hline 11 March & $\begin{array}{l}259(3.4) \\
188(2.5)\end{array}$ & $\begin{array}{l}591(2.7) \\
234(1.1)\end{array}$ & $\begin{array}{l}723(1.8) \\
187(0.5)\end{array}$ & $\begin{array}{l}Q_{z} \\
M_{z}\end{array}$ & $\begin{array}{l}\text { 仓े } \\
\text { 众 }\end{array}$ \\
\hline 14 March & $\begin{array}{c}998(14.0) \\
58(0.8)\end{array}$ & $\begin{array}{l}1909(9.8) \\
1381(7.1)\end{array}$ & $\begin{array}{l}3775(11.4) \\
1738(5.2)\end{array}$ & $\begin{array}{c}Q_{z} \\
M_{z}\end{array}$ & $\begin{array}{l}\hat{U} \\
\hat{1}\end{array}$ \\
\hline 16 March & $\begin{array}{l}445(6.8) \\
730(11.1)\end{array}$ & $\begin{array}{l}773(4.3) \\
857(4.8)\end{array}$ & $\begin{array}{l}2421(7.6) \\
2183(6.9)\end{array}$ & $\begin{array}{c}Q_{z} \\
M_{z}\end{array}$ & $\begin{array}{l}\hat{U} \\
\hat{1}\end{array}$ \\
\hline 22 March & $\begin{array}{r}113(1.6) \\
52(0.7)\end{array}$ & $\begin{array}{l}331(1.7) \\
179(0.9)\end{array}$ & $\begin{array}{l}793(2.2) \\
354(1.0)\end{array}$ & $\begin{array}{c}Q_{Z} \\
M_{z}\end{array}$ & $\begin{array}{l}\hat{\imath} \\
\hat{1}\end{array}$ \\
\hline
\end{tabular}



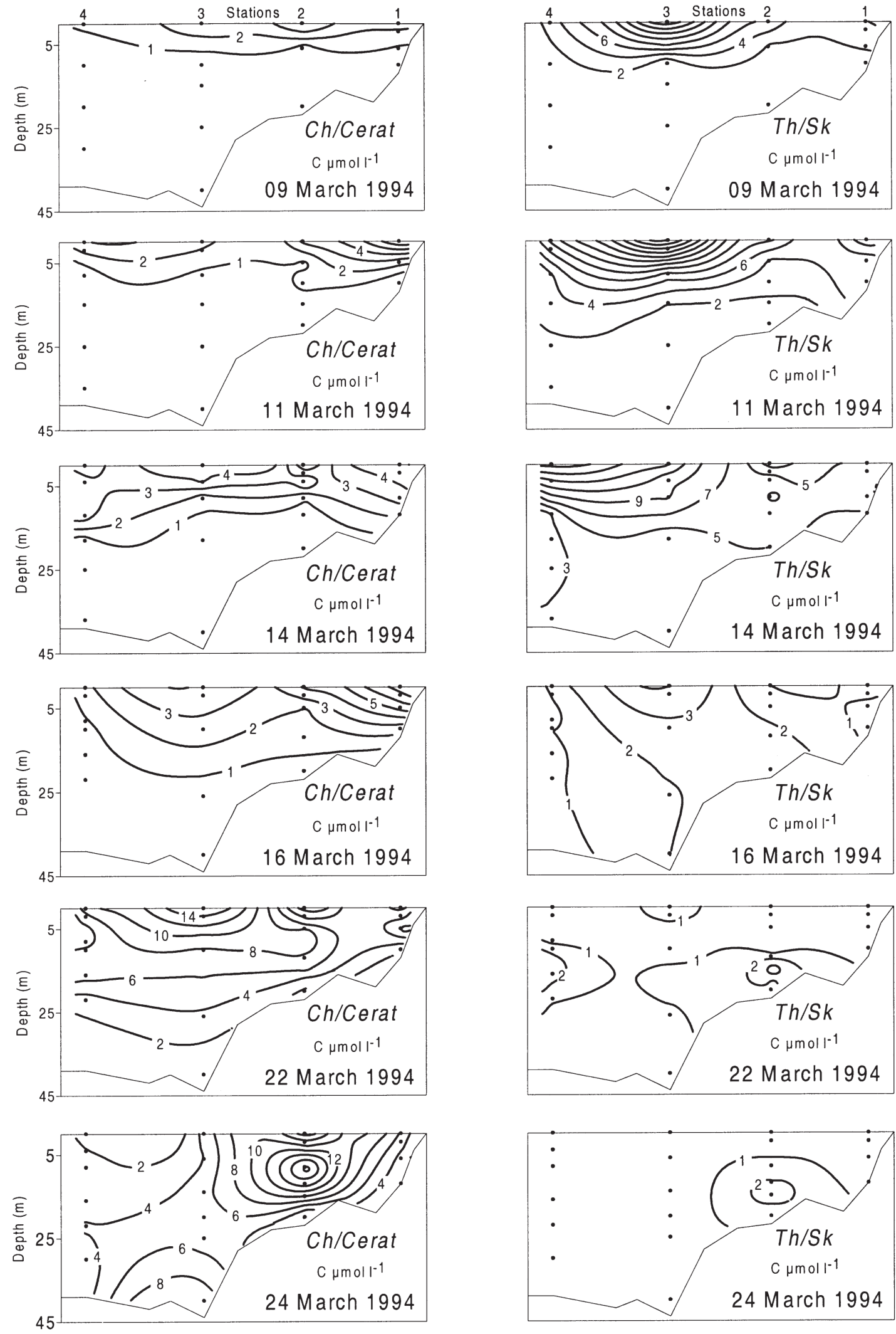

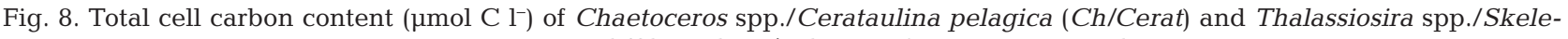
tonema costatum (Th/Sk) in the Ría de Vigo from 9 to 24 March 1994 

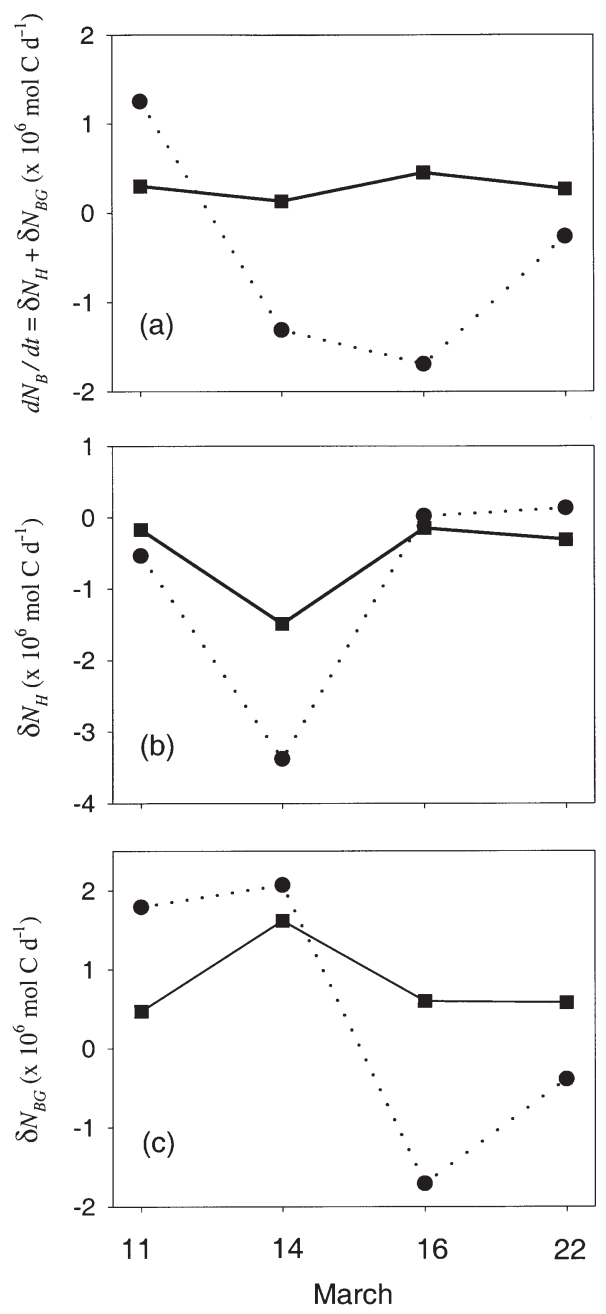

Fig. 9. (a) Total, $\mathrm{d} N_{\mathrm{B}} / \mathrm{d} t=\delta N_{H}+\delta N_{B G}$ (b) hydrographic, $\delta N_{H}$ and (c) biogeochemical, $\delta N_{B G}$, rate of change of Chaetoceros spp./Cerataulina pelagica (solid line) and Thalassiosira spp./ Skeletonema costatum (dotted line) biomass in the Ría de Vigo from 11 to 22 March 1994

fluxes on 14 March (mean vertical velocities: $Q_{z}=$ $11.7 \mathrm{~m} \mathrm{~d}^{-1}, M_{z}=4.4 \mathrm{~m} \mathrm{~d}^{-1}$ ) illustrates strong upward transport of water and mixing during upwelling. The lowest vertical convective and diffusive flux values were observed on 11 March (mean velocities: $Q_{z}=2.6 \mathrm{~m} \mathrm{~d}^{-1}$, $\left.M_{z}=2.1 \mathrm{~m} \mathrm{~d}^{-1}\right)$ and especially on $22 \operatorname{March}\left(Q_{z}=1.8 \mathrm{~m}\right.$ $\left.\mathrm{d}^{-1}, M_{z}=0.9 \mathrm{~m} \mathrm{~d}^{-1}\right)$, corresponding to periods of slower circulation in the Ría.

\section{Phytoplankton and nutrient dynamics}

The instantaneous rate of biomass change of both assemblages for the whole of the Ría $\left(\mathrm{d} N_{\mathrm{B}} / \mathrm{d} t=\delta N_{H}+\right.$ $\delta N_{B G}$ ) are shown in Fig. 9a. The changes associated with the hydrographic component $\left(\delta N_{H}\right.$, Fig. 9b) are the result of the balance between physical inputs minus physical outputs due to the residual circulation. The changes associated with the biogeochemical component $\left(\delta N_{B G}\right.$, Fig. $\left.9 \mathrm{c}\right)$ are those occurring once the balance caused by residual circulation is subtracted. The variation in the phytoplankton biomass due to this component comprises the balance between gains (growth and any other biological response that allow phytoplankton to remain in the water column, such as positive buoyancy) and losses (grazing and removal from water column due to sinking and death).

The Chaetoceros spp./Cerataulina pelagica assemblage was selected during all the sampling period (Fig. 9a) at rates between $0.13 \times 10^{6} \mathrm{~mol} \mathrm{C} \mathrm{d}^{-1}$ on 14 March and $0.45 \times 10^{6} \mathrm{~mol} \mathrm{C} \mathrm{d}^{-1}$ on 16 March. Selection occurred despite hydrographic losses (Fig. 9b), which were especially important during upwelling on 14 March $\left(-1.49 \times 10^{6} \mathrm{~mol} \mathrm{C} \mathrm{d}^{-1}\right)$. Consequently, the biogeochemical component was always positive (Fig. 9c) and compensated the hydrographic losses. The highest biogeochemical gain occurred on 14 March $\left(1.62 \times 10^{6}\right.$ mol $\mathrm{C} \mathrm{d}^{-1}$ ), which corresponds to a carbon specific net growth rate of $\delta N_{B G} \times \mathrm{C}^{-1}=0.35 \mathrm{~d}^{-1}$ (Fig. 10), where C is the mean carbon biomass (mol C) of the Chaetoceros spp./C. pelagica assemblage. The Thalassiosira spp./ Skeletonema costatum assemblage, however, was negatively selected from 14 March onwards (Fig. 9a). The loss on 14 March was due to physical exportation $\left(-3.38 \times 10^{6} \mathrm{~mol} \mathrm{C} \mathrm{d}^{-1}\right)$ towards the open ocean (Fig. 9b), because the biogeochemical component (Fig. 9c) was positive (max. $2.07 \times 10^{6} \mathrm{~mol} \mathrm{C} \mathrm{d} \mathrm{C}^{-1}$ ). Biogeochemical processes (Fig. 9c) caused the total losses of Thalassiosira spp./S. costatum on 16 and 22 March (Fig. 9a). The highest biogeochemical loss on 16 March $(-1.71 \times$ $10^{6} \mathrm{~mol} \mathrm{C} \mathrm{d}^{-1}$ ) corresponds to a carbon specific net growth rate of $\delta N_{B G} \times \mathrm{C}^{-1}=-0.72 \mathrm{~d}^{-1}$ (Fig. 10). Therefore, the main differences in the behaviour of the 2 assemblages were due to the biogeochemical compo-

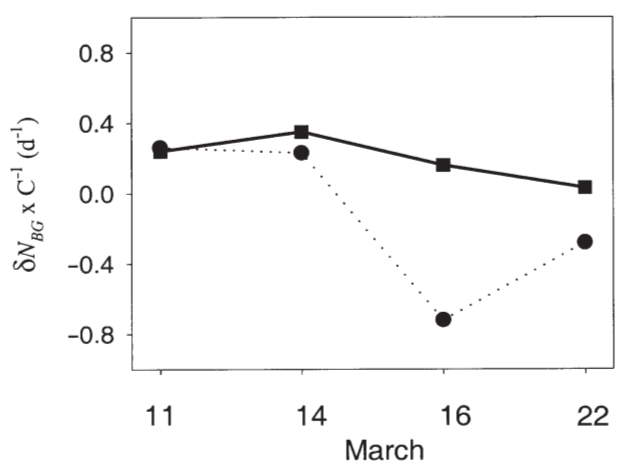

Fig. 10. Net carbon specific growth rate $\left(\delta N_{B G} \times \mathrm{C}^{-1} ; \mathrm{d}^{-1}\right)$ of Chaetoceros spp./Cerataulina pelagica (solid line) and Thalassiosira spp./Skeletonema costatum (dotted line) in the Ría de Vigo from 11 to 22 March 1994 
nent during the upwelling relaxation when Thalassiosira spp./S. costatum suffered strong carbon specific loss rates while Chaetoceros spp./C. pelagica had low but positive specific growth rates (Fig. 10). Another significant difference between the 2 assemblages occurred on 14 March. The biogeochemical gain of Chaetoceros spp./C. pelagica $\left(1.62 \times 10^{6} \mathrm{~mol} \mathrm{C} \mathrm{d}^{-1}\right)$ compensated its hydrographic loss $\left(-1.49 \times 10^{6} \mathrm{~mol} \mathrm{C} \mathrm{d}^{-1}\right)$ while the biogeochemical gain $\left(2.07 \times 10^{6} \mathrm{~mol} \mathrm{C} \mathrm{d}^{-1}\right)$ of Thalassiosira spp./S. costatum was 1.6 times lower than its hydrographic loss $\left(-3.38 \times 10^{6} \mathrm{~mol} \mathrm{C} \mathrm{d}^{-1}\right)$ (Fig. 9b,c). This difference was mainly due to the carbon specific net growth rates: $0.35 \mathrm{~d}^{-1}$ for Chaetoceros spp./C. pelagica compared to $0.23 \mathrm{~d}^{-1}$ for Thalassiosira spp./S. costatum (Fig. 10). The carbon specific net
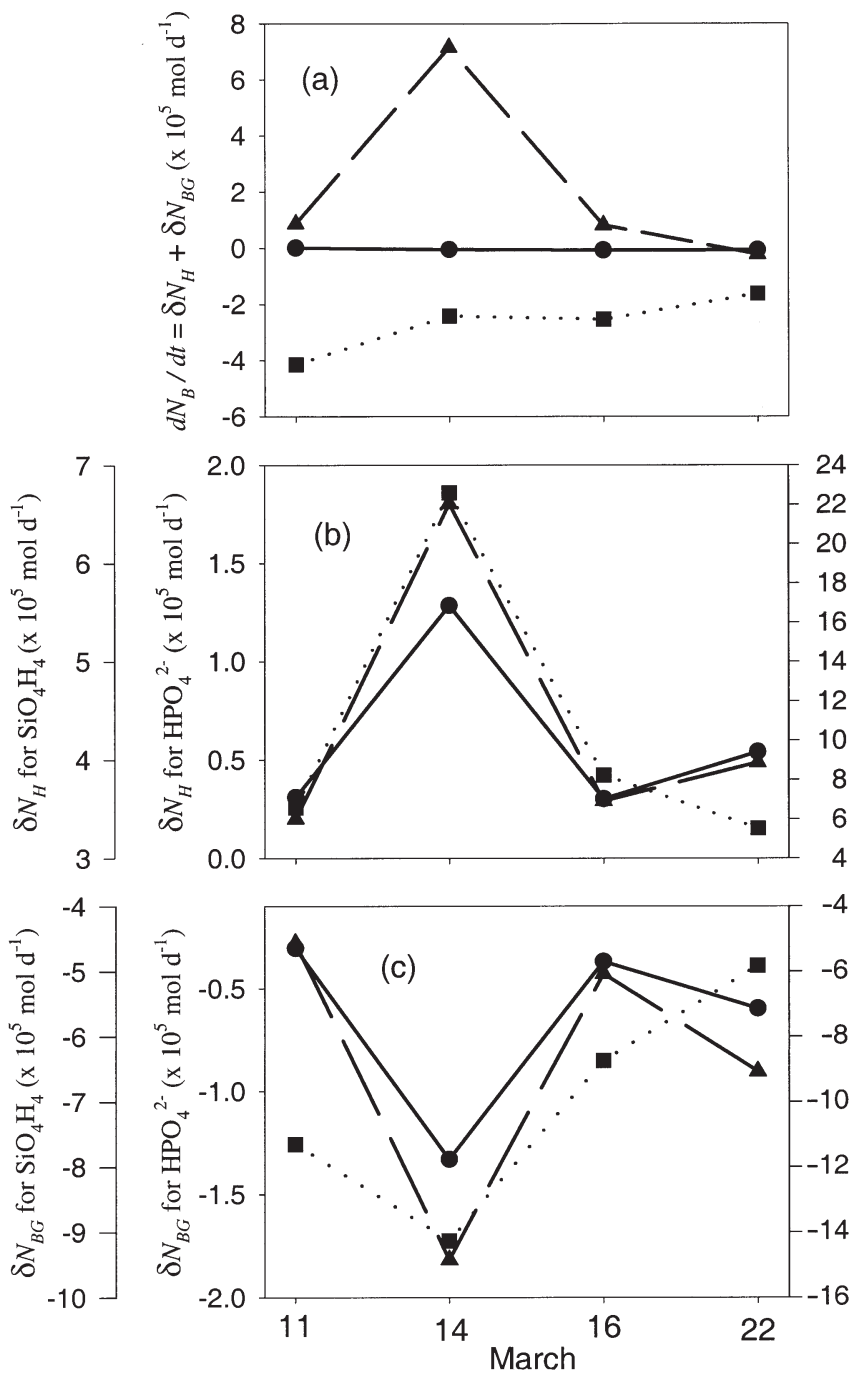

7
0
0
0
0
0
0
0
0
0
0
0
0

Fig. 11. (a) Total, $\mathrm{d} N_{\mathrm{B}} / \mathrm{d} t=\delta N_{H}+\delta N_{B G \text { r }}$ (b) hydrographic, $\delta N_{H}$, and (c) biogeochemical, $\delta N_{B G}$, rate of change of nutrients in the Ría de Vigo from 11 to 22 March 1994. Dashed line: $\mathrm{NO}_{3}{ }^{-}$; dotted line: $\mathrm{SiO}_{4} \mathrm{H}_{4}$; and solid line: $\mathrm{HPO}_{4}{ }^{2-}$ losses due to hydrographic component were similar $\left(-0.32 \mathrm{~d}^{-1}\right.$ and $-0.38 \mathrm{~d}^{-1}$ respectively).

The instantaneous rate of change in nutrients $\left(\mathrm{d} N_{\mathrm{B}} / \mathrm{d} t\right)$ is given in Fig. 11a. $\delta N_{H}$ (Fig. 11b), as for phytoplankton biomass, is the result of inputs minus outputs of nutrients due to residual circulation. For nutrient changes, the biogeochemical component $\delta N_{B G !}$ can be generally considered as the balance between remineralisation and uptake, but may also include other geochemical processes such as flocculation, redisolution or precipitation (Prego 1993).

The net physical balance of $\mathrm{NO}_{3}{ }^{-}$exceeded the biogeochemical one (Fig. 11a) except on 22 March, when both processes were equal (Fig. 11b,c). On 14 March the physical component caused a net gain in $\mathrm{NO}_{3}{ }^{-}$of $22 \times 10^{5} \mathrm{~mol} \mathrm{~d}^{-1}$. The biogeochemical component was also intense on this day $\left(-15 \times 10^{5} \mathrm{~mol}\right.$ $\mathrm{d}^{-1}$ ) but did not compensate for the $\delta N_{H}$ gain caused by upwelling and, therefore, the total net balance in the surface layer was positive for $\mathrm{NO}_{3}^{-}\left(7 \times 10^{5} \mathrm{~mol} \mathrm{~d}^{-1}\right)$. During all of the sampling period hydrographic and biogeochemical processes caused a balance in $\mathrm{HPO}_{4}{ }^{2-}$ (Fig. 11a-c). Biogeochemical processes removed $\mathrm{SiO}_{4} \mathrm{H}_{4}$ in excess with respect to the net hydrographic gains (Fig. 11a-c) and this caused a net loss of this nutrient throughout with a gradual decrease until the end of the sampling period (Fig. 11a).

Stepwise multiple regression was performed independently on the biogeochemical variation in each nutrient and the biogeochemical change in biomass of major diatom groups (Cerataulina, Chaetoceros, Coscinodiscus, Rhizoselinia, Skeletonema, Thalassiosira spp. and other diatoms) in the upper layer of the 3 boxes in order to assess the relationship between the different diatom groups and nutrients. Up to $88 \%$ of the variability in Cerataulina pelagica and other diatoms (which include Asterionella, Cocconeis, Melosira, Pseudonitzschia, Stauroneis and Thalassionema) is related to $\mathrm{NO}_{3}{ }^{-}$bigeochemical variation (Table 4). The explained variability between the same diatom groups and $\mathrm{HPO}_{4}{ }^{2-}$ was $71 \%$. No relationship was found between these diatoms and silicates. However, variations in Thalassiosira spp. and Skeletonema costatum biomass explained $73 \%$ of the variation in $\mathrm{SiO}_{4} \mathrm{H}_{4}$. Note that the slopes of the regressions in Table 4 include not only nutrient uptake by diatoms but also nutrient uptake by other organisms such as bacteria, pico- and nanoplankton as well as other biogeochemical processes which occur in the surface layer such as grazing, death and nutrient regeneration. 
Table 4. Significant multiple stepwise regression between biogeochemical variation of $\mathrm{NO}_{3}{ }^{-}, \mathrm{HPO}_{4}{ }^{2-}$ and $\mathrm{SiO}_{4} \mathrm{H}_{4}\left(\mu \mathrm{mol} \mathrm{l}^{-1} \mathrm{~d}^{-1}\right)$

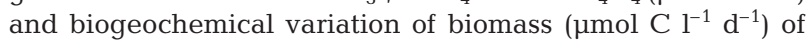
major groups of diatoms on the surface layer of the 3 boxes (see Fig. 1), $\mathrm{n}=12$. Other diatoms include the following genera: Asterionella, Cocconeis, Melosira, Pseudo-nitzschia, Stauroneis and Thalassionema. $\mathrm{p}$ : level of significance of the total regression, intercepts and slopes. NS: not significant

\begin{tabular}{|c|c|c|}
\hline $\begin{array}{l}\text { Dependent variable } \mathrm{NO}_{3} \\
\mathrm{r}^{2}=0.88\end{array}$ & $F_{2,9}=33.99$ & $\mathrm{p}<0.001$ \\
\hline Intercept & $0.41 \pm 0.38$ & NS \\
\hline Cerataulina pelagica & $-17.10 \pm 3.19$ & $\mathrm{p}<0.001$ \\
\hline Other diatoms & $-4.56 \pm 1.3$ & $p=0.006$ \\
\hline & Dependent variable $\mathrm{HPO}_{4}{ }^{2-}$ & $\mathrm{p}<0.005$ \\
\hline Intercept & $-0.01 \pm 0.03$ & NS \\
\hline Other diatoms & $-0.25 \pm 0.096$ & $\mathrm{p}=0.027$ \\
\hline Cerataulina pelagica & $-0.57 \pm 0.23$ & $\mathrm{p}=0.038$ \\
\hline $\begin{array}{l}\text { Dependent variable } \mathrm{SiO} \\
\mathrm{r}^{2}=0.74\end{array}$ & ${ }_{4}{ }^{\mathbf{H}_{4}}{ }_{F_{2,9}}=12.77$ & $\mathrm{p}<0.005$ \\
\hline Intercept & $-1.07 \pm 0.16$ & $\mathrm{p}<0.001$ \\
\hline Skeletonema costatum & $-0.40 \pm 0.12$ & $p=0.007$ \\
\hline Thalassiosira spp. & $-0.17 \pm 0.06$ & $\mathrm{p}=0.013$ \\
\hline
\end{tabular}

\section{DISCUSSION}

It is often difficult to segregate the effects of physical and biogeochemical processes on the phytoplankton assemblage in upwelling zones due to the tight coupling between these 2 processes. CTD, nutrient and phytoplankton species profiles are used routinely to identify the dominant hydrographic and biogeochemical conditions, but the distribution patterns of hydrographic and biological variables are restricted to static descriptions rather than dynamic analyses (Painchaud et al. 1996). Box models can provide more quantitative information on the effects of major processes on the dynamics of phytoplankton (Chang \& Carpenter 1985). In this paper an improved 2-D kinematic box model based on the thermohaline properties of the water column was used to gain deeper insight into the effects of biogeochemical and physical processes on 2 diatom assemblages. Box model residual circulation characterised horizontal and vertical fluxes during 2 distinct hydrographic phases, which temporally and spatially separated diatom assemblages dominated by Thalassiosira spp./Skeletonema costatum and Chaetoceros spp./Cerataulina pelagica.

Rosón et al. (1997) correlated the convective residual flux in the Ría de Arousa with the mean upwelling index to evaluate the accuracy of residual circulation derived from the box model. The correlation was relatively high $\left(r^{2}=0.47\right)$. In this study this correlation was even higher $\left(r^{2}=0.60\right)$. Vertical convective fluxes were clearly coupled with the horizontal convective fluxes (Tables 2 \& 3). The highest horizontal transport and strongest vertical mixing were associated with rapid circulation during upwelling, while lower values were related to periods of upwelling relaxation. On 14 March the fluxes reached a maximum (Tables 2 \& 3) when Thalassiosira spp. and Skeletonema costatum biomass was high and the biomasss of Chaetoceros spp./Cerataulina pelagica was significantly lower. Reduction of horizontal fluxes in the upper and lower layer of the boxes on March 16 (Table 2), which indicated relaxation of upwelling, coincided with the disappearance of Thalassiosira spp./S. costatum biomass from the water column and an increase in the biomass of Chaetoceros spp./C. pelagica. Chaetoceros spp./C. pelagica dominated the phytoplankton biomass on 22 March, when the lowest horizontal and vertical fluxes were recorded. It can be concluded that the reduction in horizontal and vertical fluxes during upwelling relaxation resulted in an accumulation of Chaetoceros spp./C. pelagica biomass and in a loss of Thalassiosira spp./S. costatum biomass in the Ría. Strong specific grazing pressure on Thalassiosira spp./S. costatum, as well as its sudden death, are 2 factors that may explain the quick demise of this assemblage during upwelling relaxation. We suggest, however, that the relatively higher growth rate of the Chaetoceros spp./C. pelagica assemblage and the possession of morphological features of Chaetoceros spp., which aid buoyancy in the water column in the absence of water column mixing, may partially explain the differences observed. The strong negative hydrographic component for Thalassiosira spp./S. costatum on 14 March indicates export of this assemblage from the Ría which is not balanced by the biogeochemical component (Fig. 9a). By comparison, although the Chaetoceros spp./C. pelagica assemblage was also exported, the high positive biogeochemical component for this assemblage resulted in its positive selection and accumulation during upwelling relaxation. This was probably aided by the spatial separation between the 2 assemblages. During upwelling the Chaetoceros spp./C. pelagica assemblage occurred in the interior of the Ría and the Thalassiosira spp./S. costatum assemblage at the mouth. Morphological features may have also influenced the selection of the 2 species. Margalef (1978) showed that phytoplankton are morphological adapted to the physical conditions that determine their selection. The centric diatoms Thalassiosira spp. and $S$. costatum form large chains and have high aggregation and sinking rates and are therefore better adapted to buoyancy during strong vertical advection (see Fig. 8, Tables 2 \& 3) and high water column mixing (Riebsell 1989, Passow 1991, Waite et al. 1992, Alldredge et al. 1995). Thalas- 
siosira spp. have a relatively higher aggregation and sinking rate and tend to sediment out of the water column faster than Chaetoceros spp., although this can depend on the relative spatial position of the 2 species (Tallberg \& Heiskanen 1998). By comparison Chaetoceros spp. possess long aerolated setae which facilitate buoyancy by causing a spiral rotation of the diatom chain in moving media (Goldsmith 1966, Zia et al. 1966, Margalef 1978), which probably aids buoyancy during the reduced horizontal and vertical fluxes observed (Tables $2 \& 3$ ). The fact that there was an increase in the hydrographic component of Thalassiosira spp./S. costatum during upwelling relaxation (Fig. 9b) supports this interpretation. The horizontal advective fluxes (Tables $1 \& 2$ ), showed that there was still an outflow of surface water during upwelling relaxation, which would suggest that previously sedimented Thalassiosira spp./S. costatum were reintroduced to the surface from the bottom layer through the residual circulation. The upwelling relaxation event which led to the selection of Chaetoceros spp./C. pelagica during spring (Figs. $3 \& 7$, Table 2) is the same as the sequence in autumn that selects red tide species such as Gymnodinium catenatum (Tilstone et al. 1994, Fermín et al. 1996, Figueiras et al. 1996).

When the box model was used to study nutrient dynamics, the results highlighted that $\mathrm{SiO}_{4} \mathrm{H}_{4}$ could be the limiting nutrient for diatoms, since $\mathrm{HPO}_{4}{ }^{2-}$ was almost in balance and $\mathrm{NO}_{3}{ }^{-}$was in excess during upwelling (Figs. 5, 6 \& 11). The stepwise regressions between biogeochemical variation in the nutrients and the biogeochemical change in the diatom assemblages (Table 4) clearly show that Thalassiosira spp./Skeletonema costatum has a higher dependence on $\mathrm{SiO}_{4} \mathrm{H}_{4}$ than all other diatom groups. During upwelling relaxation there was a biogeochemical increase in Chaetoceros spp./Cerataulina pelagica biomass, but in the regression of nutrients against diatom biomass only C. pelagica correlated significantly with $\mathrm{NO}_{3}{ }^{-}$and $\mathrm{HPO}_{4}{ }^{2-}$. C. pelagica sediments rapidly from the water column and does not possess morphological features that aid flotation (Round et al. 1990). This suggests that an increase in $C$. pelagica biomass is more dependent on the consumption of $\mathrm{NO}_{3}{ }^{-}$and $\mathrm{HPO}_{4}{ }^{2-}$, whereas the increase and accumulation of Chaetoceros spp. is probably more influenced by its morphology than nutrient consumption, since there was no significant relationship between biogeochemical increase of Chaetoceros spp. biomass and biogeochemical net nutrient loss. The application of the box model to nutrient consumption by diatoms is a novel idea and provides a useful tool for assessing diatom consumption of nutrients. The biogeochemical balance from a particular box also implies losses of diatom carbon due to grazing, sinking, death, as well as nutrient regenera- tion and recycling, and nutrient consumption by other plankton groups. These factors do not permit us to determine the carbon-specific uptake of each nutrient but do allow us to assess the dependency of diatom dominance on nutrient consumption. Waite et al. (1992) suggested that the sedimentation of Thalassiosira spp. is due to a greater sensitivity to $\mathrm{NO}_{3}{ }^{-}$depletion. The covariation between biogeochemical increase of Thalassiosira spp./S. costatum biomass and less biogeochemical comsumption of $\mathrm{SiO}_{4} \mathrm{H}_{4}$ would also suggest a high sensitivity to $\mathrm{SiO}_{4} \mathrm{H}_{4}$. Our results illustrate that the accumulation of Thalassiosira spp./S. costatum standing stock is short lived in the Ría. Strong upwelling results in its exportation towards the shelf and upwelling relaxation causes its sedimentation. Chaetoceros spp./C. pelagica assemblage is selected in the Ría waters by its high growth rate during upwelling and by its buoyancy (or low sinking rate) during upwelling relaxation.

Mann (1992) has shown that strong vertical mixing followed by stratification of the water column is the key to high productivity of phytoplankton throughout the world oceans. Previous work in the area has shown that Chaetoceros spp. are selected during upwellingdownwelling relaxation events when primary production values are highest in the Ría (Tilstone et al. 1999). Diatoms such as Chaetoceros spp. form an important link in the food chain to zooplankton and fish larvae (Mann 1992). Since they are able to remain in the water column during upwelling relaxation, they are probably crucial in maintaining high fish and shellfish productivity in the Rías.

\section{CONCLUSIONS}

Physical processes have a greater influence on the Thalassiosira spp./Skeletonema costatum biomass than biogeochemical processes during upwelling, which cause a net export of this diatom assemblage towards the shelf. The dominance of Thalassiosira spp./S. costatum biomass in the water column during upwelling is associated with high nutrient concentrations. These diatoms have a strong dependency on $\mathrm{SiO}_{4} \mathrm{H}_{4}$. The effect of physical processes on the Chaetoceros spp./ Cerataulina pelagica biomass was lower than on Thalassiosira spp./S. costatum and they were compensated by the higher growth rate of Chaetoceros spp./C. pelagica. The abundance of Chaetoceros spp. during the relaxation event seems to be associated with a high initial biomass during the previous upwelling event and morphological characteristics that aid buoyancy. The selection of C. pelagica is more dependent on $\mathrm{NO}_{3}{ }^{-}$ and $\mathrm{HPO}_{4}{ }^{2-}$ consumption. The results imply that high mixing and nutrient levels during upwelling cause 
Thalassiosira spp./S. costatum dominance and a net export of this biomass from the Ría. The net retention of Chaetoceros spp./C. pelagica biomass during upwelling relaxation will be directly available to the fish and shellfish communities of the Ría.

Acknowledgements. We are grateful to the members of the Oceanography team at the Instituto de Investigacións Mariñas, Vigo, who participated in the sampling and analysis of nutrients and hydrographic parameters. We would like to thank an anonymous referee whose comments greatly improved this manuscript. This work was financed partly by the Xunta de Galicia (project Xuga 40205 B 92) and by the Comisión Interministerial de Ciencia y Tecnología (CICYT; project AMB92-0165). E.G.F. was supported by a grant from the Plan de Formación de Recursos Humanos of the Oriente University, Venezuela. B.M.M. was financed by an FPU studentship from the Spanish Ministry of Education and Culture and G.H.T. by the European Commission MAST programme (MAS3-CT96-5022).

\section{LITERATURE CITED}

Alldredge AL, Gotschalk C, Passow U, Riebsell U (1995) Mass aggregation of diatom blooms: insights from a mesocosm study. Deep-Sea Res 42:9-27

Álvarez-Salgado XA, Fraga F, Pérez FF (1992) Determination of nutrient salt by automatic methods both in sea and brackish water: the phosphate blank. Mar Chem 39: 311-319

Álvarez-Salgado XA, Rosón G, Pérez FF, Figueiras FG, Pazos Y (1996) Nitrogen cycling in an estuarine upwelling system, the Ría de Arousa (NW Spain). I. Short-time-scale patterns of hydrodynamic and biogeochemical circulation. Mar Ecol Prog Ser 135:259-273

Bakun A (1973) Coastal upwelling indices, west coast of North America. 1946-71. NOAA Tech Rep NMFS SSRF671. US Dept of Commerce, Seattle

Barber RT, Smith WO Jr (1980) The role of circulation, sinking and vertical migration in physical sorting of phytoplankton in the upwelling center at $15^{\circ} \mathrm{S}$. In: Richards FA (ed) Coastal upwelling. American Geophysical Union, Washington, DC, p 366-371

Beer T (1983) Environmental oceanography. Pergamon Press, Oxford

Blanton JO, Atkinson LP, Fernández de Castillejo F, Lavín A (1984) Coastal upwelling off Rías Bajas, Galicia, Northwest Spain. I. Hydrographic studies. Rapp P V Réun Cons Int Explor Mer 183:79-90

Blasco D, Estrada M, Jones B (1980) Relations between the phytoplankton distribution and composition and the hydrography in the upwelling region near Cabo Corbeiro. Deep-Sea Res 27:799-821

Brink KH, Jones BH, Van Leer JC, Mooers CNK, Stuart DW, Stevenson MR, Dugdale RC, Heburn GW (1980) Physical and biological structure and variability in an upwelling center off Peru near $15^{\circ} \mathrm{S}$ during March 1977. In: Richards FA (ed) Coastal upwelling. American Geophysical Union, Washington, DC, p 473-495

Chang J, Carpenter EJ (1985) Blooms of the dinoflagellate Gyrodinium aureolum in a long island estuary: box model analysis of bloom maintenance. Mar Biol 89:83-93

Chase J (1975) Wind-driven circulation in a spanish estuary. Estuar Coastal Mar Sci 3:303-310
Conley CJ, Malone TC (1992) Annual cycle of dissolved silicate in Chesapeake Bay: implications for the production and fate of phytoplankton biomass. Mar Ecol Prog Ser 81: 121-128

Downing AL (1971) Forecasting the effects of polluting discharges on natural waters. II. Estuaries and Coastal waters. Int J Environ Stud 2:221-226

Dyer KR (1973) Estuaries, a physical introduction. John Wiley and Sons, New York

Edler L (1979) Recommendations for marine biological studies in the Baltic Sea. Phytoplankton and chlorophyll. Baltic Mar Biol 5:38

Fermín EG, Figueiras FG, Arbones B, Villarino ML (1996) Short-time scale development of a Gymnodinium catenatum population in the Ría de Vigo (NW Spain). J Phycol 32: 212-221

Figueiras FG, Niell FX (1987) Distribución estacional y espacial del fitoplancton en la Ría de Pontevedra (NO de España). Invest Pesq 51:293-320

Figueiras FG, Wyatt T, Álvarez-Salgado XA, Jenkinson I (1995) Advection, diffusion, and patch development of red tide organisms in the Rías Baixas. In: Lassus P, Arzul G, Erard E, Gentin P, Marcaillou C (eds) Harmful marine algal blooms. Technique et Documentacion-Lavoisier, Intercept Ltd, Paris p 579-584

Figueiras FG, Gómez E, Nogueira E, Villarino ML (1996) Selection of Gymodinium catenatum under downwelling conditions in the Ría de Vigo. In: Yasumoto T, Oshima Y, Fukuyo Y (eds) Harmful and toxic algal blooms. Intergovernmental Oceanographic Commission of UNESCO, Paris, p 215-218

Fraga F, Margalef R (1979) Las rías gallegas. In: Estudio y explotación del mar en Galicia. Cursos y congresos, University of Santiago, Spain, p 101-121

Gallegos CL (1992) Phytoplankton photosynthesis, productivity and species composition in an eutrophic estuary: comparison of bloom and non-bloom assemblages. Mar Ecol Prog Ser 81:257-267

Goldsmith HL (1966) Red cells and Rouleaux in shear flow. Science 153:1406-1407

Guillard RRL, Killam P (1977) The ecology of marine planktonic diatoms. In: Werner D (ed) The biology of diatoms. University California Press, Berkeley, p 372-469

Hansen HP, Grassshoff K (1983) Automated chemical analysis. In: Grasshoff K, Ehrardt M, Kremling K (eds) Methods of seawater analysis. Verlag Chemie, Weinheim, p 347-395

Hidy GM (1972) A review of recent air-sea interaction research. Bull Am Meteorol Soc 53:1083-102

Hood RR, Abbott MR, Huyer A (1991) Phytoplankton and photosynthetic light response in the coastal transition zone off northern California in June 1987. J Geophys Res 96: 14769-14780

Huntsman SA, Barber RT (1977) Primary production off northwest Africa: the relationship to wind and nutrient conditions. Deep-Sea Res 24:25-33

Jones BH, Halpern D (1981) Biological and physical aspects of a coastal upwelling event observed during March-April 1974 off northwest Africa. Deep-Sea Res 28:71-81

Kononen K, Nommann S, Hansen G, Breuel G, Gupalo E (1992) Spatial heterogeneity and dynamics of vernal phytoplankton species in the Baltic Sea in April-May 1986. J Plankton Res 14:107-125

Lavín A, Díaz del Río G, Cabanas JM, Casas G (1991) Afloramiento en el noroeste de la Penísula Ibérica. Indices de afloramiento para el punto $43^{\circ} \mathrm{N} 11^{\circ} \mathrm{W}$ : período $1966-1989$. Inf Tec Inst Esp Oceanogr 91:1-40 
Legendre L (1990) The significance of microalgal blooms for fisheries and for the export of particulate organic carbon in oceans. J Plankton Res 12:681-699

Legendre L, Legendre P (1983) Numerical ecology. Elsevier, Amsterdam

Lohrenz SE, Fahnenstiel GL, Redalje DG (1994) Spatial and temporal variations of photosynthetic parameters in relation to environmental conditions in coastal waters of the Northern Gulf of Mexico. Estuaries 17:779-795

Lopez-Jamar E, Cal RM, González G, Hanson RB, Rey J, Santiago G, Tenore KR (1992) Upwelling and outwelling effects on the benthic regime of the continental shelf off Galicia, NW Spain. J Mar Res 50:465-488

Mann KH (1992) Physical influences on biological processes: how important are they? In: Payne AIL, Brink KH, Mann $\mathrm{KH}$, Hilborn RS (eds) Benguela trophic functioning. Afr J Mar Sci 12:107-121

Mann KH (1993) Physical oceanography, food chains, and fish stocks: a review. ICES J Mar Sci 50:105-119

Margalef R (1958) Temporal succession and spatial heterogeneity in phytoplankton. In: Buzzati-Traverso AA (ed) Perspectives in marine biology. University California Press, Berkeley, p 323-348

Margalef R (1972) Fitoplancton de la región de afloramiento del noreste de Africa I. Pigmentos y producción. Res Exp Cient 1:23-51

Margalef R (1978) Life forms of phytoplankton as survival alternatives in an unstable environment. Oceanol Acta 1: 493-509

Mouriño C, Fraga F (1985) Determinación de nitratos en agua de mar. Invest Pesq 49:81-6

Officer CB (1980) Box models revisited. In: Hamilton P, McDonald KB (eds) Estuarine and wetland processes with emphasis on modeling. Plenum, New York, p 65-114

Officer CB, Ryther JH (1980) The possible importance of silicon in marine eutrophication. Mar Ecol Prog Ser 3:83-91

Otto L (1975) Oceanography of the Ría de Arousa (NW Spain). Konik Meteor International Medelingen en Verlan No. 96, p 1-210

Painchaud J, Lefaivre D, Therriault JC, Legendre L (1996) Bacterial dynamics in the upper St. Lawrence estuary. Limnol Oceanogr 41(8):1610-1618

Passow U (1991) Species-specific sedimentation and sinking velocities of diatoms. Mar Biol 108:449-455

Prego R (1993) Flows and budgets of nutrient salts and organic carbon in relation to a red tide in the Ría of Vigo (NW Spain). Mar Ecol Prog Ser 79 289-302

Prego R, Fraga F (1992) A simple model to calculate the residual flows in a Spanish Ría. Hydrographic consequences in the Ría of Vigo. Estuar Coast Shelf Sci 34:603-615

Ragueneau O, Varela EDB, Tréguer $\mathrm{P}$, Quéguiner B, Del Amo Y (1994) Phytoplankton dynamics in relation to the biogeochemical cycle in a coastal ecosystem of western Europe. Mar Ecol Prog Ser 106:157-172

Riebsell U (1989) Comparisons of sinking and sedimentation rate measurements in a diatom winter/spring bloom. Mar Ecol Prog Ser 54:109-119

Ríos AF, Nombela M, Pérez FF, Rosón G, Fraga F (1992) Calculation of runoff to an estuary. Ría de Vigo. Sci Mar 56: 29-33

Rosón G, Álvarez-Salgado XA, Pérez FF (1997) A non-stationary box model to determine residual fluxes in a partially mixed estuary, based on both thermohaline properties: application to the Ría de Arousa (NW Spain). Estuar Coast Shelf Sci 44:249-262

Editorial responsibility: Otto Kinne (Editor),

Oldendorf/Luhe, Germany
Rosón G, Álvarez-Salgado XA, Pérez FF (1999) Carbon cycling in a large coastal embayment affected by winddriven upwelling: short-time scale variability and spatial differences. Mar Ecol Prog Ser 176:215-230

Round FE, Crawford RM, Mann DG (1990) The diatoms, biology and morphology of the genera. Cambridge University Press, New York

Shiller AM (1996) The effect of recycling traps and upwelling on estuarine chemical flux estimates. Geochim Cosmochim Acta 60:3177-3185

Smetacek VS (1985) Role of sinking in diatom life-history cycles: ecological, evolutionary and geological significance. Mar Biol 84:239-251

Smith WO, Heburn GW, Barber RT, O'Brien JJ (1983) Regulation of phytoplankton communities by physical processes in upwelling systems. J Mar Res 41:539-556

Strathmann R (1967) Estimating the organic carbon content of phytoplankton from cell volume or plasma volume. Limnol Oceanogr 12:411-418

Tallberg P, Heisaken AS (1998) Species-specific phytoplankton sedimentation in relation to primary production along an inshore-offshore gradient in the Baltic Sea. J Plankton Res 20:2053-2070

Tilman D (1977) Resource competition between planktonic algae: an experimental and theoretical approach. Ecology 58:338-348

Tilstone GH, Figueiras FG, Fraga F (1994) Upwelling-downwelling sequences in the generation of red tides in a coastal upwelling system. Mar Ecol Prog Ser 112:241-53

Tilstone GH, Figueiras FG, Fermín EG, Arbones B (1999) Significance of nanophytoplankton photosynthesis and primary production in a coastal upwelling system (Ría de Vigo, NW Spain). Mar Ecol Prog Ser 183:13-27

Tiselius P, Kuylenstierna M (1996) Growth and decline of a diatom spring bloom: phytoplankton species composition, formation of marine snow and the role of heterotrophic dinoflagellates. J Plankton Res 18:133-155

Tolomio C, Solazzi A, Marzochhi M, Cavolo F (1993) The influence of tidal rhythms on phytoplankton and on some hydrological parameters in the Sacca del Canarin (Po River Delta). Lav Soc Venez Sci Nat 18:191-214

Tont SA, Platt T (1979) Fluctuations in the abundance of phytoplankton on the californian coast. In: Naylor E, Hartnoll RG (eds) Cyclic phenomena in marine plants and animals. Pergamon Press, Oxford, p 11-18

UNESCO (1983) Algorithms for computation of fundamental properties of seawater. UNESCO Tech Pap Mar Sci 44:1-53

Utermöhl H (1958) Zur Vervollkommnung der quantitativen Phytoplankton-Methodik. Mitt Int Ver Theor Angew Limnol 9:1-38

Villarino ML, Figueiras FG, Jones KJ, Álvarez-Salgado XA, Richard J, Edwards A (1995) Evidence of in situ diel vertical migration of a red-tide microplankton species in Ría de Vigo (NW Spain). Mar Biol 123:607-617

Vives F, Lopez-Benito M (1957) El fitoplancton de la Ría de Vigo, desde Julio de 1955 a Junio 1956. Invest Pesq 10: $19-120$

Waite A, Bienfang PK, Harrison PJ (1992) Spring bloom sedimentation in a subarctic ecosystem. I. Nutrient sensitivity. Mar Biol 114:119-129

Yentsch CS, Menzel DW (1963) A method for the determination of phytoplankton chlorophyll and phaeophytin by fluorescence. Deep-Sea Res 10:221-231

Zia IYZ, Cox RG, Mason SR (1966) Chains of particles in shear flow. Science 153:1405-1406

Submitted: September 27, 1999; Accepted: March 24, 2000

Proofs received from author(s): October 2, 2000 